\title{
Implications of Deformation Along the East Flank of the Charleston-Nebo Thrust Plate, Central Utah
}

U.S. GEOLOGICAL SURVEY PROFESSIONAL PAPER 1170-F

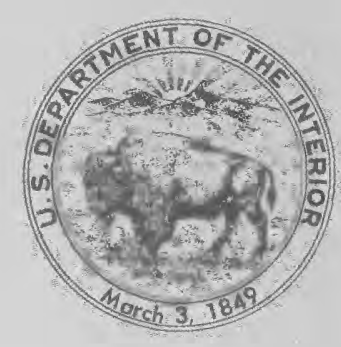




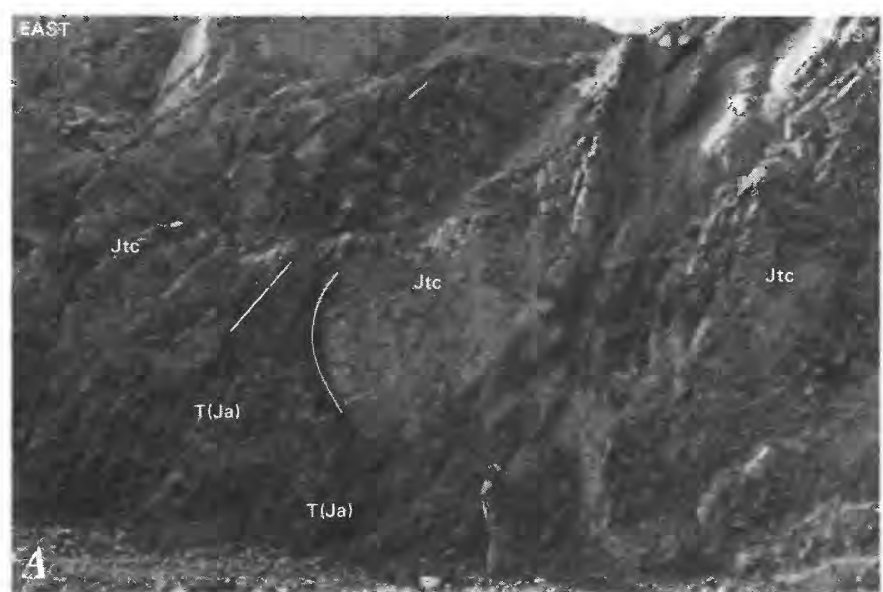

FIGURE 4.-Photographs showing intrusive aspects of the Arapien Shale. Exposures are near Thistle, Utah.

A. View looking southward at beds of the Arapien Shale (T(Ja)) that intrude and deform tilted beds of the Middle Jurassic Twin Creek Limestone ( $\mathrm{Jtc}$ ), part of the erosional escarpment formed on the Charleston-Nebo thrust plate.

$B$. View looking eastward at beds of the Eocene-Paleocene Flagstaff Limestone (Tf) that have been bowed up to a near-vertical position by an intrusive mass of the Arapien Shale (T(Ja)).

Roadbed being prepared for new tracks of the Denver and Rio Grande Western Railroad shown in upper right corner.

folds whose trend and position reflect the underlying salt diapirs. Erosion has destroyed large parts of the folds, and, in places, only one limb of a fold is exposed as a belt of complexly deformed rocks with the other limb either completely removed or concealed beneath surficial deposits. As a result of this recurrent movement of the driving salt, I see the Arapien as a sedimentary unit that is in intrusive rather than unconformable contact with the overlying sedimentary rocks (fig. 4).

The downwarped strata between the diapiric folds form elongate synclines. The width of a syncline at any one locality reflects the distance between the axial parts of adjacent diapiric folds. Thus, for example, the Gunnison Plateau (fig. 1), in part, is a south-plunging syncline bounded on both its east and west flanks by diapiric folds, and along its north border by part of a diapiric fold.

\section{DESCRIPTION OF DEFORMED AREAS}

\section{BORDERING SYNCLINE}

Tilted remnants of a former continuous cover of younger Cretaceous and Tertiary rocks delineate the sinuous, easterly facing erosional escarpment formed

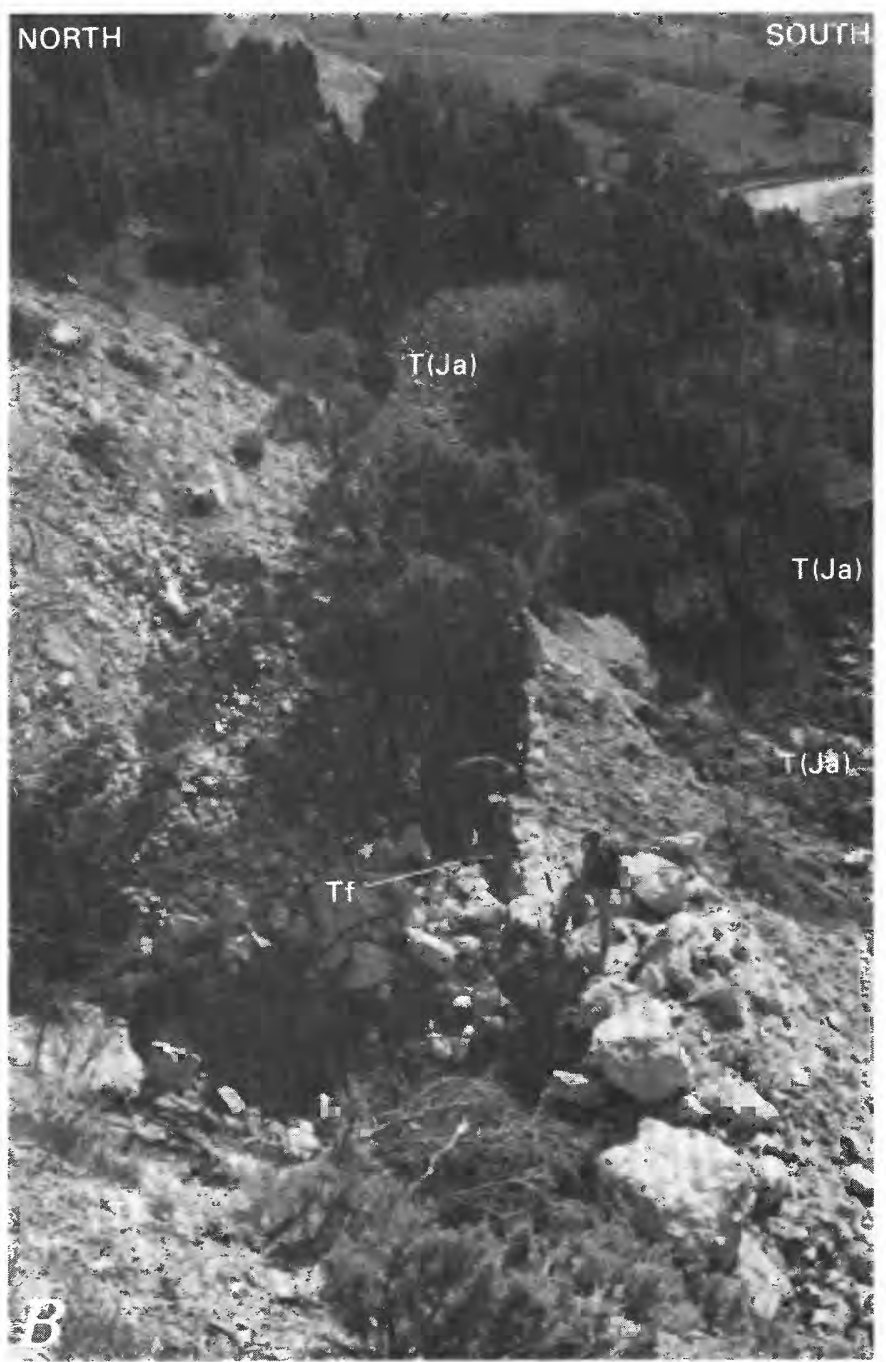

on the Charleston-Nebo thrust plate. In general, the strike of these Cretaceous and Tertiary remnants closely parallels the escarpment; these remnants invariably dip away from the escarpment. For example, those remnants along that part of the escarpment that trends northerly, dip generally easterly, or northeasterly; elsewhere, near the north end of the Santaquin embayment (where the escarpment trends easterly) the remnants dip southerly, or westerly. Wherever exposed, these outward-dipping beds are very localized, and within distances that range from about 150 to $1,525 \mathrm{~m}(500$ to $5,000 \mathrm{ft}$ ) away from the escarpment, the beds reverse dip and are inclined toward the escarpment to form a narrow to broad, sinuous syncline that borders and parallels the escarpment (fig. 3). I believe that the specific width of this syncline at any one place is determined by the distance between an exposed diapiric fold 
and the escarpment. Where the diapiric fold is close to the escarpment, as in the Salt Creek area (Pole Creek diapiric fold, fig. 1, no. 12) the syncline is narrow; where the fold diverges from the escarpment, the syncline widens and is broad.

\section{AREAS OF LOCALIZED DEFORMATION}

In this section, nine areas that show this localized deformation (fig. 3) are described. Eight areas are alike: tilted beds of clastic rocks of the North Horn Formation, of Late Cretaceous-Paleocene age (table 2), unconformably overlie older Paleozoic or Mesozoic beds that form the escarpment. A short distance away from the escarpment these beds reverse dip and are inclined toward the thrust plate. In one locality on Thistle Creek, the tilted beds that overlie the escarpment are volcanic rocks of the Moroni Formation, 32-33 m.y. old (R. F. Marvin, U.S. Geological Survey, written commun., 1983), and therefore of Oligocene(?) age. Photographic overviews of six of the nine localities are given in figure 5 .

\section{SALT CREEK AREA}

In Salt Creek Canyon, about $10 \mathrm{~km}(6 \mathrm{mi})$ northeast of Nephi (fig. 3), the escarpment, formed on the Charleston-Nebo thrust plate, consists of a series of overturned beds that range from the Oquirrh Formation of Permian and Pennsylvanian age to the Twin Creek Limestone of Middle Jurassic age (fig. 6). These overturned strata dip $45-70^{\circ}$ northwestward and are overlain eastward, with profound angular unconformity, by a mantle of reddish-brown beds, right side up, composed of conglomerate, sandstone, and siltstone, which are here considered to be part of the North Horn Formation. (In the past these strata have been assigned both to the Price River Formation (Schoff, 1951 p. 627), and tentatively to the undivided Indianola Group (Black, 1965, p. 71)). Best exposures of the structural relations between the mantling North Horn strata and the escarpment are along the east valley wall of Salt Creek Canyon in secs. 8, 9, 16, and 17, T. 12 S., R. 2 E. Near Ponderosa Campground, North Horn beds rest directly on overturned Navajo and Twin Creek strata of the thrust plate and dip about $15^{\circ}$ southeastward (away from the thrust plate) (fig. 5A). This southeastward dip persists away from the thrust plate for about $150 \mathrm{~m}(500 \mathrm{ft})$, at which point the North Horn strata reverse dip and are inclined about $30^{\circ}$ northwestward toward the plate.
BLACK CANYON AREA

In and near Black Canyon, east of Evans Ridge (fig. 3), North Horn strata adjacent to the escarpment (secs. 26 and 27 , T. 11 S., R. 2 E.) strike northeasterly, dip southeasterly, and unconformably overlie limestone beds of the Oquirrh Formation of similar strike and dip (fig. 7). About $0.7 \mathrm{~km}(0.5 \mathrm{mi})$ southeast of the escarpment (in the SW1/4 of sec. 24 , T. 11 S., R. 2 E.), North Horn beds have reversed dip and are inclined westward at about $20^{\circ}$. I estimate that the reversal in dip of the North Horn beds occurs about $525 \mathrm{~m}(1,700 \mathrm{ft})$ southeast of the escarpment.

This reversal of North Horn beds reflects the crest of a diapiric fold exposed in Nebo Creek (S1/2 of sec. 24, T. 11 S., R. 2 E.). The crest, expressed by vertical to steeply inclined beds of the Indianola Group, is overlain unconformably by North Horn strata that dip easterly east of Nebo Creek and westerly west of the creek. I interpret the inclined North Horn strata to be the flanks of the diapiric fold.

\section{TAYLOR FORK AND SANTAQUIN CANYON AREAS}

In the neighboring Taylor Fork and Santaquin Canyon areas (fig. 3), North Horn beds that fill a small northeast-facing notch cut into the escarpment have been deformed into a small northeast-plunging syncline. In Taylor Fork, the North Horn beds dip easterly; as the beds are traced southeastward into Santaquin Canyon, they gradually assume a northeasterly strike and dip northwesterly (fig. 8).

In Taylor Fork, the escarpment is overlain by eastward-dipping reddish-brown beds of conglomerate, sandstone, and siltstone of the North Horn Formation (fig. $5 B$ ). Other workers (Metter, 1955; Hintze, 1962; Davis, 1983) have assigned these beds to the Colton Formation, chiefly because they overlie a light-gray bed of limestone identified by the other workers as the Flagstaff Limestone. The presence of a thick conglomerate in the clastic units that overlie the limestone, however, suggests to me that the limestone may be but a thick Flagstaff-like lens intercalated in North Horn strata. In my opinion, then, the beds in question are more correctly assigned to the North Horn Formation than to the Colton.

Best exposures are along the west valley wall of Taylor Fork (a tributary to Santaquin Creek) and occupy parts of secs. 21,28 , and 33 , T. 10 S., R. 2 E. In this general area, the Charleston-Nebo thrust plate is represented by Paleozoic beds that are right side up, 
FIGURE 5.-Photographs of localities discussed in text. In all localities, clastic beds of the North Horn Formation unconformably overlie the escarpment formed on the Charleston-Nebo allochthon. Dashed lines delineate angular unconformity between the North Horn beds and underlying units. The North Horn beds invariably dip away from the escarpment.

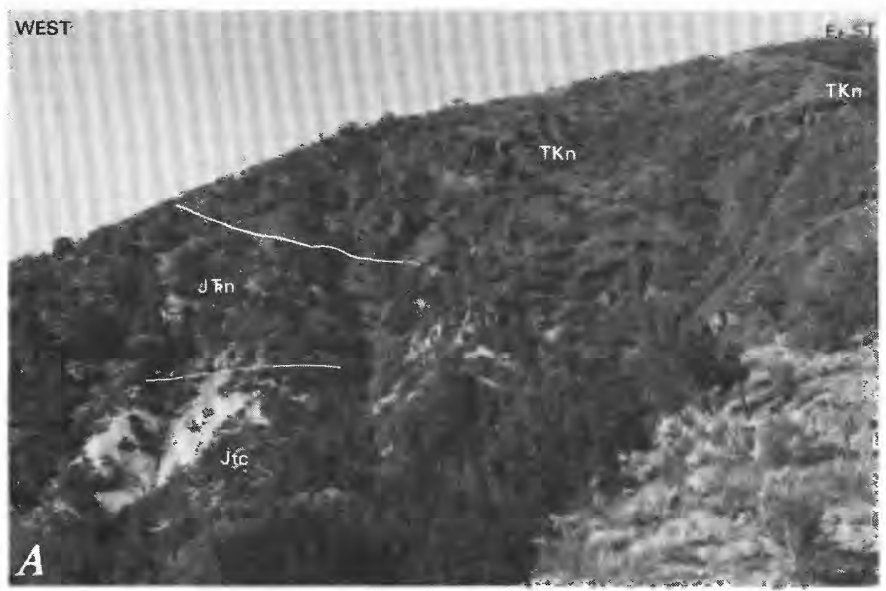

A.-View looking northward at exposure in Salt Creek Canyon showing eastward-dipping reddish-brown sandstone beds of the North Horn Formation (TKn) unconformably overlying overturned beds of the Navajo Sandstone (JTn) and Twin Creek Limestone (Jtc). The Navajo and Twin Creek strata dip northwestward (away from viewer) and are part of the escarpment. The eastward dip of the North Horn strata lessens and is almost horizontal near the east (right) edge of the photograph. Farther to the east (right), beyond the edge of the photograph, the North Horn beds reverse dip and are inclined westward toward the escarpment. See fig. 6 for geologic map of this locality.

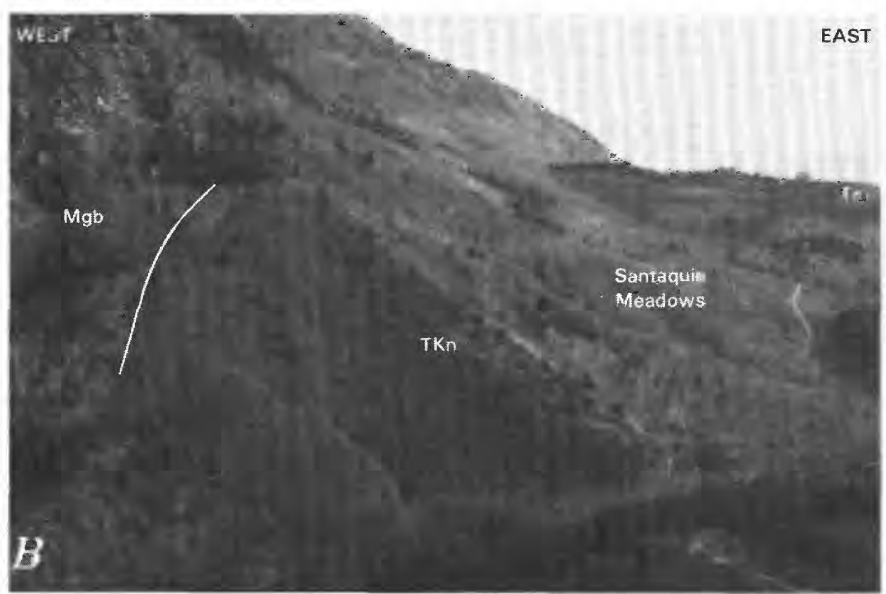

B.-View looking northward into Taylor Fork at an exposure along the east flank of Dry Mountain near the head of Santaquin Canyon. Eastward-dipping clastic beds of the North Horn Formation (TKn), which strike northerly and dip easterly, unconformably overlie beds of the Great Blue Limestone (Mgb). The Great Blue Limestone beds are part of the erosional escarpment formed on the Charleston-Nebo thrust plate. Volcanic units of the Moroni Formation (Tm) unconformably overlie the North Horn Formation, and seemingly are deformed along with the North Horn beds. See fig. 8 for geologic map of this locality.

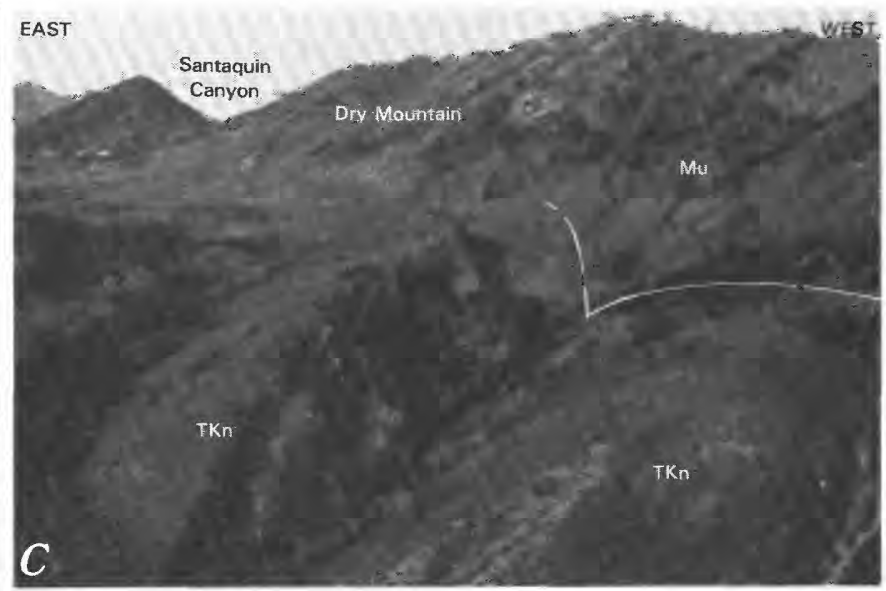

C.-View looking southward along the east flank of Dry Mountain, near Red Lake, showing eastward-tilted clastic beds of the North Horn Formation (TKn) unconformably overlying eastward-tilted undivided Mississippian strata $(\mathrm{Mu})$ that are part of the escarpment formed on the Charleston-Nebo thrust plate. See fig. 9 for geologic map of this locality.

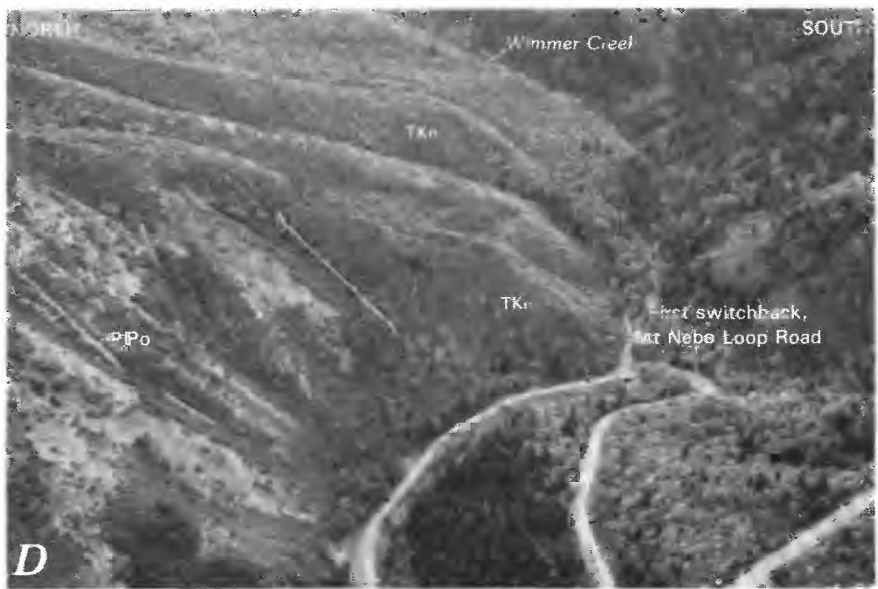

D.- View looking eastward at exposures near the head of Payson Canyon. In this locality, the escarpment bends sharply to the northeast as it conforms to a reentrant cut into the thrust plate. As a result, the clastic beds of the North Horn Formation (TKn), that unconformably overlie the escarpment, strike northeast and dip southeast. The escarpment is formed by beds of the Oquirrh Formation (PPO) that also strike northeast and dip southeast. See fig. 10 for geologic map of this locality. 


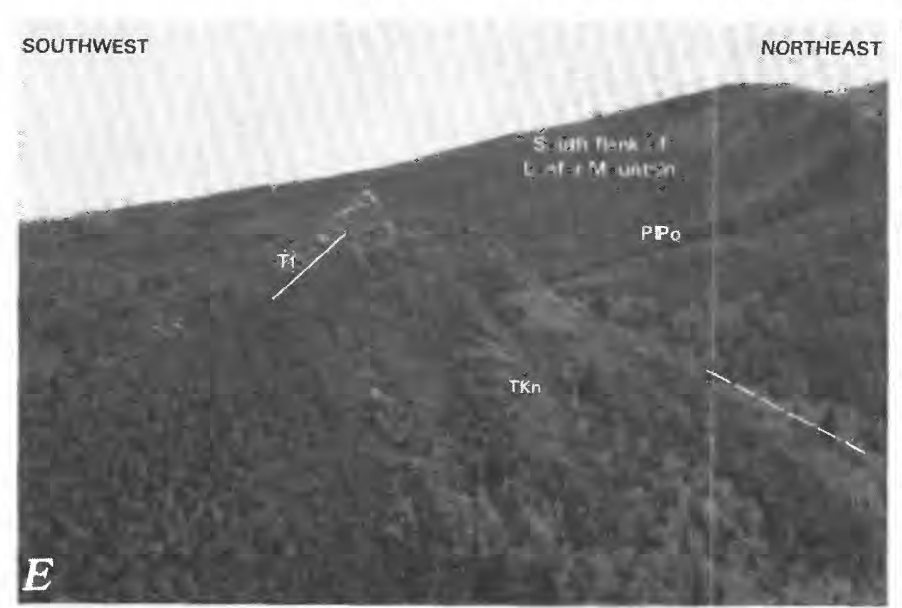

E.-View looking northwestward at a small hogback, near head of Bennie Creek, along the south flank of Loafer Mountain. The hogback slopes southerly and is formed of clastic beds of the North Horn Formation (TKn) capped by a thin light-gray bed of the Flagstaff Limestone (Tf). The North Horn beds rest unconformably on units of the Oquirrh Formation (PPO) that strike northwesterly and dip northeasterly, and form part of the east-trending escarpment. See fig. 10 for geologic map of this locality.

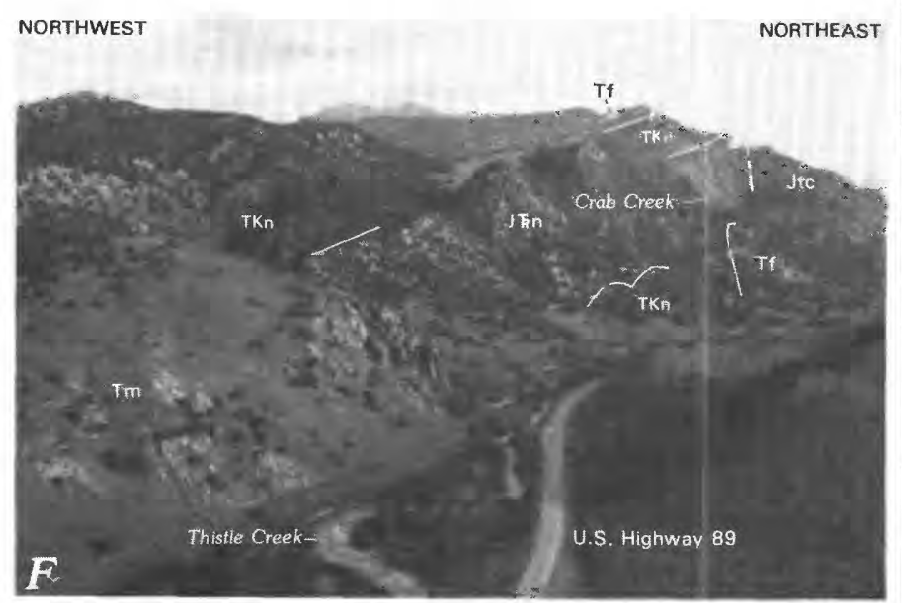

F.-View looking northerly along the west valley wall of Thistle Creek. The escarpment formed on the Charleston-Nebo thrust plate is exposed in a small gap eroded in a mantle of folded younger Cretaceous and Tertiary units. The escarpment is represented by steep eastward-dipping beds of the Navajo Sandstone (J $\mathrm{Fn}$ ) and the Twin Creek Limestone (Jtc). The folded Cretaceous-Tertiary mantle is represented by sedimentary beds of the North Horn Formation (TKn) and the Flagstaff Limestone (Tf), and by volcanic units of the Moroni Formation (Tm). Only remnants of the sedimentary cover are preserved along the base of the west valley wall of Thistle Creek, but the cover is extensively exposed on the uplands both east and west of the creek. In general, the beds that form the cover west of the exposed escarpment dip westerly; those that form the cover east of the escarpment dip easterly. See fig. 11 for geologic map of this locality. strike northerly, and dip easterly between $35^{\circ}$ and $55^{\circ}$ (fig. 8). These beds are overlain by North Horn strata that strike about $\mathrm{N} .10^{\circ} \mathrm{W}$. and dip northeasterly at about $30^{\circ}$. The North Horn strata are overlain by volcanic rocks of the Moroni Formation (Oligocene?). Although exposures are poor, the volcanic rocks near the escarpment also appear to be tilted eastward at dips comparable to those in the underlying North Horn beds. I estimate that the North Horn beds and the overlying cover of sedimentary and volcanic rocks maintain an eastward dip away from the thrust plate for about $915 \mathrm{~m}(3,000 \mathrm{ft})$ at which point they flex upward, reverse dip, and are inclined gently toward the thrust plate.

As the North Horn beds exposed in Taylor Fork are traced southeastward into Santaquin Canyon, they gradually swing about and assume a northeasterly strike and a northwesterly dip (fig. 8). The change is best expressed by the thick Flagstaff-like limestone lens that crops out extensively in the southern halves of secs. 33 and 34, T. 10 S., R. 2 E. In detail, the escarpment in Santaquin Canyon trends easterly and is composed of eastward-dipping beds of the Oquirrh Formation. These units are unconformably overlain by North Horn beds that strike about N. $85^{\circ} \mathrm{E}$. and dip about $20^{\circ}$ to the northwest. Although exposures are poor, it appears that the volcanic rocks of the Moroni Formation also conform with the strike and dip of the underlying North Horn units. The poor exposures conceal the trace of the synclinal axis. I estimate the distance from the escarpment to the synclinal axis to to be about $1,525 \mathrm{~m}$ $(5,000 \mathrm{ft})$.

\section{RED LAKE AREA}

Near Red Lake (fig. 3), where eastward-dipping North Horn strata overlie the east flank of Dry Mountain, the geologic relations along the escarpment (fig. $5 \mathrm{C}$ ) duplicate those previously noted farther south in Taylor Fork. West of Red Lake, the thrust plate consists of beds of Mississippian limestone that strike north and dip $20-45^{\circ}$ eastward (fig. 9). These limestone beds are overlain unconformably by reddish-brown conglomerate, sandstone, and siltstone beds of the North Horn Formation that also strike northward, but dip eastward about $30^{\circ}$. The exposures, along the west valley wall of the Right Fork of Peteetneet Creek (in Payson Canyon), occupy parts of secs. 10, 15, 16, and 21, T. 10 S., R. 2 E. Although the area is thickly forested, the geologic relations are quite clear, chiefly because the deep reddish-brown of the North Horn 


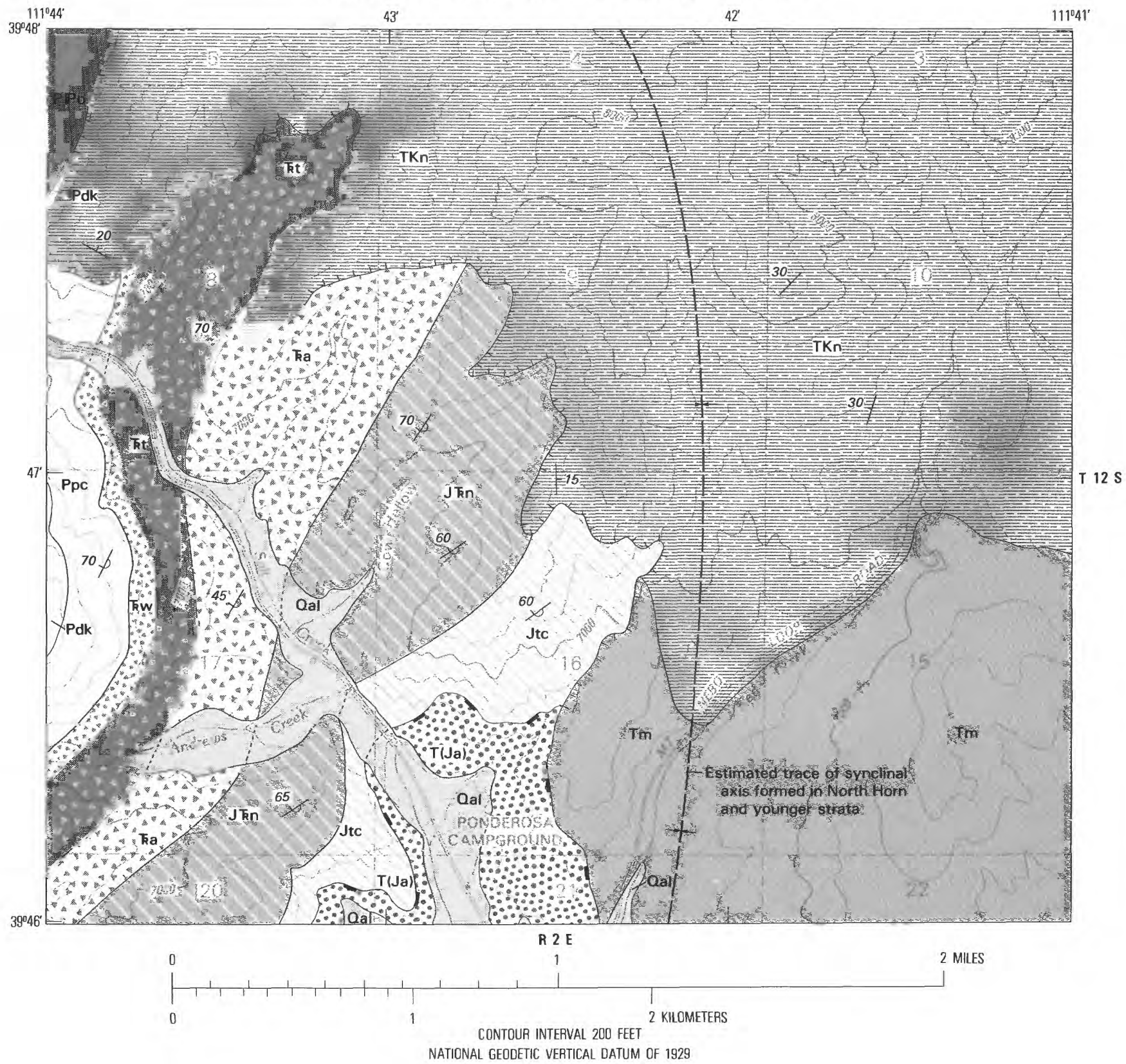

Formation contrasts sharply with the more somber hues of the Paleozoic limestones.

Thick foliage and a thin veneer of detritus mask the bedrock that underlies the area east of these tilted North Horn strata, essentially the Shingle Mill Hollow area (secs. 22 and 27, T. 10 S., R. 2 E.). Consequently, I am uncertain as to the exact attitude of the beds that underlie this specific locality. Good exposures of the concealed strata are in road cuts directly south of this locality (fig. 8), and I have projected the attitudes of these exposed strata into the Shingle Mill Hollow area. The trace of the synclinal axis, shown in figure 9, is based on these projected attitudes. Assuming that the trace of the synclinal axis is approximately correct, the eastward dip of the North Horn strata away from the escarpment persists for about $1,220 \mathrm{~m}(4,000 \mathrm{ft})$ before the beds reverse dip, flex upward, and are inclined toward the escarpment at dips that range from $10^{\circ}$ to about $20^{\circ}$.

\section{HEAD OF PAYSON CANYON}

All exposures discussed thus far lie along the western margin of the wide Santaquin embayment (fig. 3). Consequently, the North Horn beds that overlie the north-trending erosional escarpment formed on the 
EXPLANATION
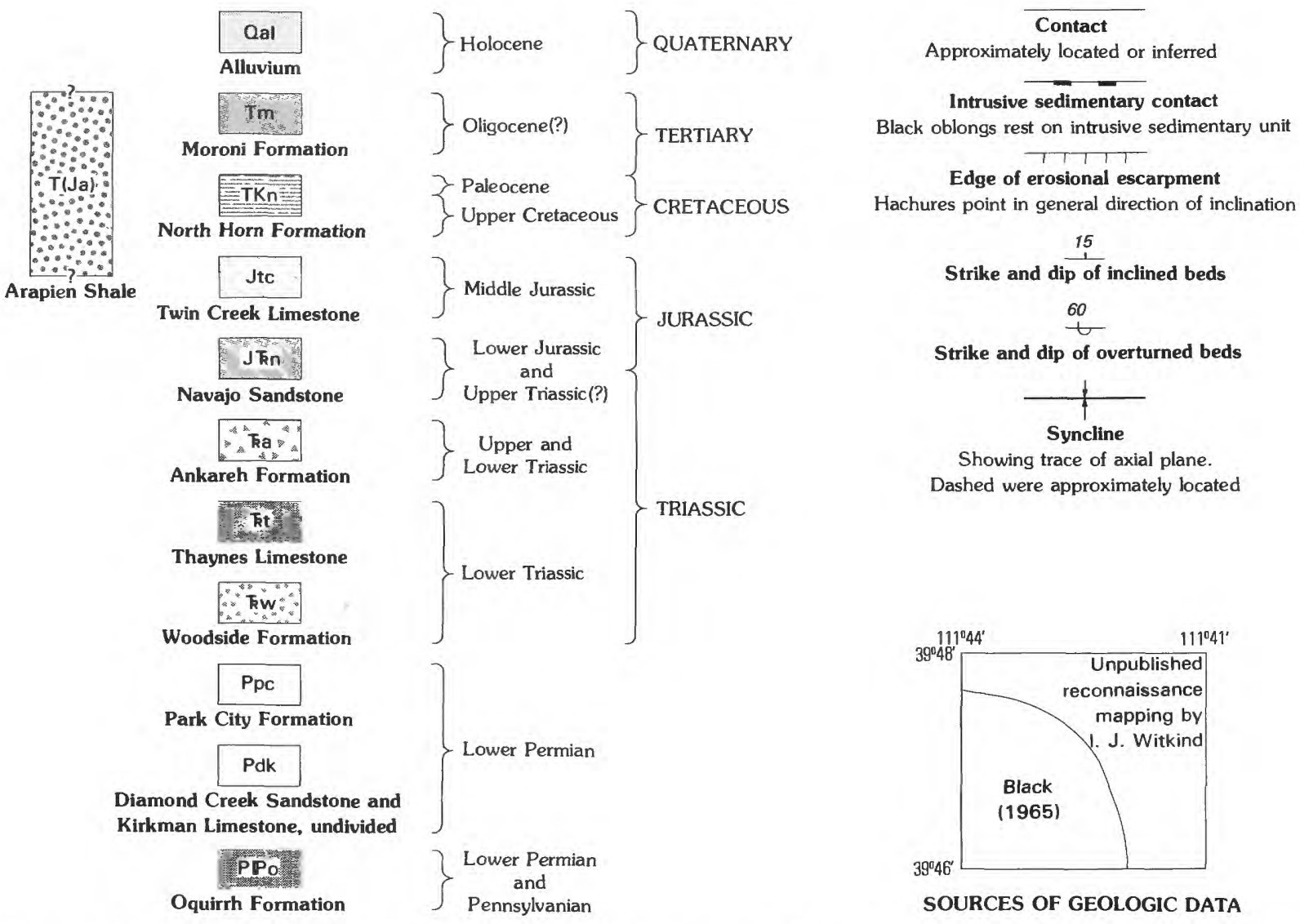

SOURCES OF GEOLOGIC DATA

Figure 6 (above and facing page).-Geologic map of the Salt Creek area. Overturned Paleozoic and Mesozoic strata that strike northeast and dip northwest mark the erosional escarpment formed on the Charleston-Nebo thrust plate. These beds are mantled by beds of the North Horn $(T K n)$ and Moroni $(T m)$ Formations. The North Horn strata that overlie the escarpment dip easterly; a short distance away from the escarpment the strata reverse dip and are inclined toward the escarpment. See fig. $5 A$ for photographic overview of this locality.

Charleston-Nebo thrust plate dip either easterly, or locally northerly, as in Santaquin Canyon. The exposures near the head of Payson Canyon are along the north side of the Santaquin embayment. The escarpment trends easterly and the overlying North Horn strata dip southerly.

Near the junction of Wimmer and Peteetneet Creeks (head of Payson Canyon) (fig. 10), limestone beds of the Oquirrh Formation, part of the escarpment, dip southeast at about $40^{\circ}$ and are unconformably overlain by tilted beds of conglomerate, sandstone, and siltstone of the North Horn Formation that also dip southeast but at about $30^{\circ}$. These relations are clearly exposed along the north valley wall of Wimmer Creek in secs. 11, 12, and 14, T. 10 S., R. 2 E., and are best examined in the northeast corner of section 14 near the first switchback in the Mt. Nebo Loop Road (fig. $5 D$ ). The southeasterly dip of the North Horn strata persists for about $915 \mathrm{~m}$
$(3,000 \mathrm{ft})$ away from the escarpment before the beds reverse dip and are inclined toward the escarpment.

\section{HEAD OF BENNIE CREEK}

The contact between the tilted south-dipping North Horn strata and the underlying beds of the Oquirrh Formation extends eastward along the north wall of Wimmer Creek, more or less concealed beneath detritus (fig. 10). The exposures form part of the south flank of Loafer Mountain. At the divide between Wimmer and Bennie Creeks, the contact is again exposed at the base of a hogback that slopes southward (fig. $5 E$ ) and that occupies parts of secs. 7 and 18, T. 10 S., R. 3 E. (unsurveyed). North Horn beds form the bulk of the hogback and are conformably overlain by a light-gray bed of the Flagstaff Limestone. The North Horn strata 

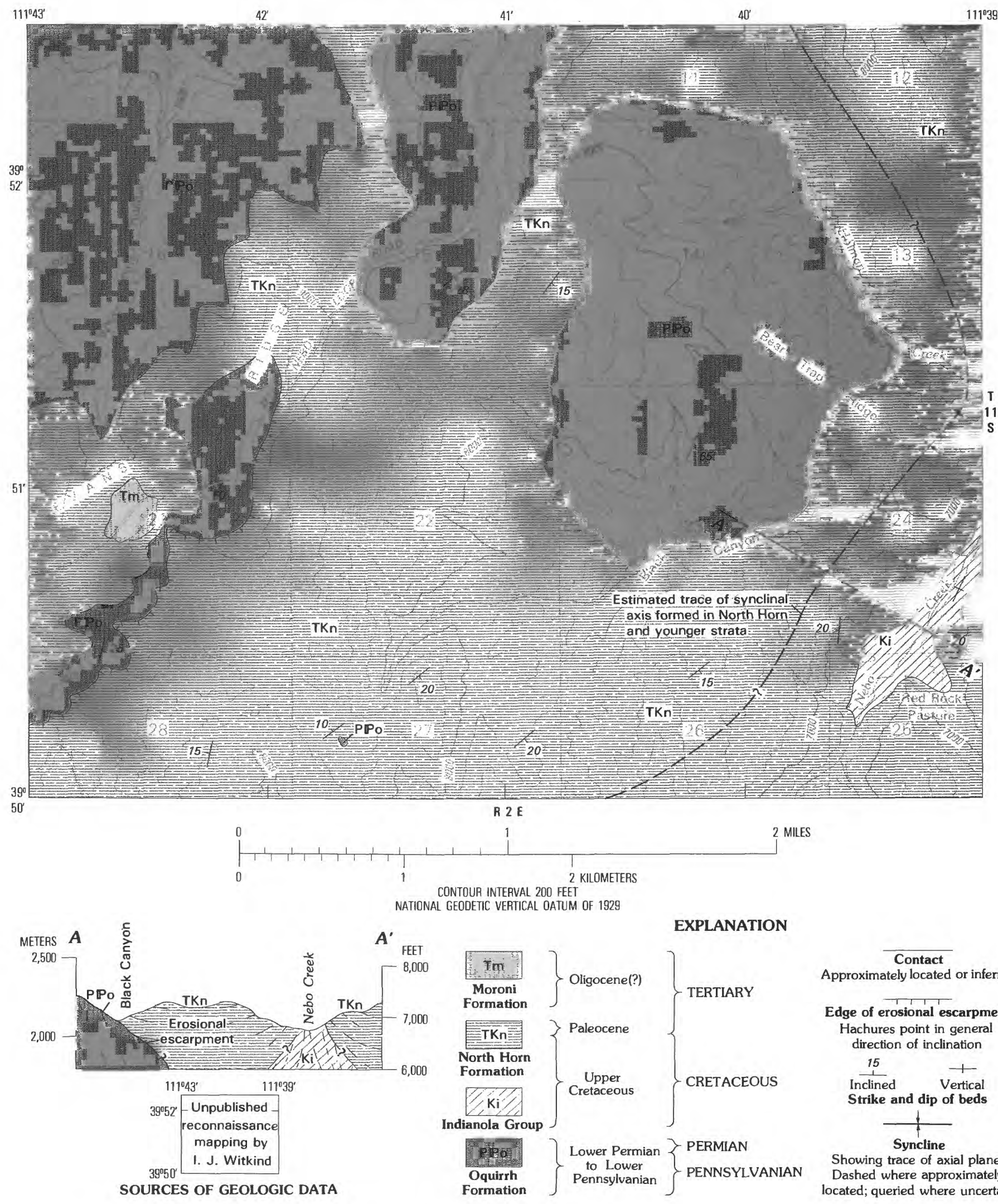

Contact

Approximately located or inferred

Edge of erosional escarpment

Hachures point in general direction of inclination

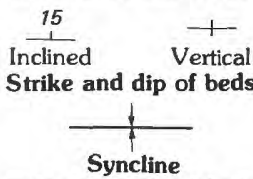

Showing trace of axial plane. Dashed where approximately located; queried where uncertain 
strike about N. $40^{\circ} \mathrm{W}$., dip about $45^{\circ}$ southwestward, and unconformably overlie beds of the Oquirrh Formation (part of the escarpment) that strike about N. $70^{\circ}$ W. and dip about $50^{\circ}$ to the northeast.

Exposures are poor and the extent of the southward tilt of the North Horn beds away from the escarpment is uncertain; I believe the beds maintain a southward dip for about $915 \mathrm{~m}(3,000 \mathrm{ft})$ before they reverse dip and are inclined toward the escarpment.

\section{EAST FLANK OF LOAFER MOUNTAIN}

As the North Horn-Oquirrh contact is traced southeastward along the north valley wall of Bennie Creek, south of Loafer Mountain, much of the contact is concealed beneath foliage and detritus. In general, the North Horn strata strike northwesterly and dip southwesterly, conforming to the north edge of the Santaquin embayment (fig. 3). Near the head of Paces Hollow (a tributary to Bennie Creek), the contact passes beneath volcanic rocks of the Moroni Formation, and these volcanic rocks, too, are tilted up along the escarpment in much the same fashion as the North Horn strata. Although exposures are poor, I estimate that the volcanic rocks maintain an easterly dip for about $760 \mathrm{~m}(2,500 \mathrm{ft})$ away from the escarpment before they reverse dip and are inclined toward the escarpment.

\section{THISTLE CREEK AREA}

The escarpment trends northeastward along the east flank of Loafer Mountain (fig. 3) and is overlain by North Horn beds that reappear from beneath the volcanics near the junction of Aggie and Thistle Creeks (fig. 11). Good exposures are along the west valley wall

FIGURE 7 (facing page).-Geologic map of an area along and near Black Canyon. Clastic beds of the North Horn Formation (TKn), which are juxtaposed against the escarpment formed on the thrust plate, strike northwest and dip southeast, and unconformably overlie units of the Oquirrh Formation (PPO) of similar strike and dip. These North Horn units reverse dip directly west of Nebo Creek reflecting the west flank of a diapiric fold (possibly a segment of the Thistle Creek fold (fig. 1, no. 11)), part of which is exposed in section 24. Cross section is not deep enough to include the Charleston-Nebo thrust fault, which is the sole of the thrust plate. of Thistle Creek some $6 \mathrm{~km}(3.5 \mathrm{mi})$ north of the small community of Birdseye. One of the best exposures occupies parts of secs. 5, 6, and 7, T. 10 S., R. 4 E., and is near the junction of Crab and Thistle Creeks (fig. $5 F$ ).

Near this stream junction, the escarpment is formed by beds of the Navajo Sandstone and Twin Creek Limestone that are right side up and that strike about N. $40^{\circ}$ E. and dip about $60^{\circ}$ to the southeast (fig. 11). These strata are overlain unconformably by beds of the North Horn Formation that also strike about N. $40^{\circ} \mathrm{E}$. but dip southeastward at about $20^{\circ}$. These North Horn strata are overlain conformably by a remnant of the Flagstaff Limestone. About $1.6 \mathrm{~km}(1 \mathrm{mi})$ southwest of this exposure, the escarpment passes beneath North Horn strata that are draped across it. North Horn beds northwest of the escarpment dip northwestward at about $15^{\circ}$; those east of the escarpment dip southeastward at about $30^{\circ}$. These southeastward-dipping North Horn beds, east of the escarpment, are overlain unconformably by beds of the Moroni Formation that also dip southeastward. East of the escarpment, all units, sedimentary as well as volcanic, dip easterly and southeasterly, and this dip persists away from the escarpment for about $610 \mathrm{~m}(2,000 \mathrm{ft})$ before all beds reverse dip and are inclined toward the escarpment.

\section{IMPLICATIONS OF THE TILTED STRATA}

In many places, the contact between the inclined North Horn beds and the escarpment is concealed beneath debris and foliage, and the impression thus created is that only here and there are North Horn beds juxtaposed against the escarpment. I believe, however, that the escarpment, at least in the area discussed here, is everywhere overlain unconformably by North Horn beds. These beds strike parallel to the trace of the escarpment and invariably dip away from it. The nine localities described above represent only the bestexposed examples of the relations between North Horn beds and the escarpment.

This localized tilting of North Horn beds seemingly reflects a major deformational episode late in the structural evolution of this part of central Utah. Four alternative interpretations to explain this tilting are considered reasonable:

1. The tilt of the North Horn beds is the result of drag along one or more high-angle normal faults that separate the North Horn beds from the escarpment. 


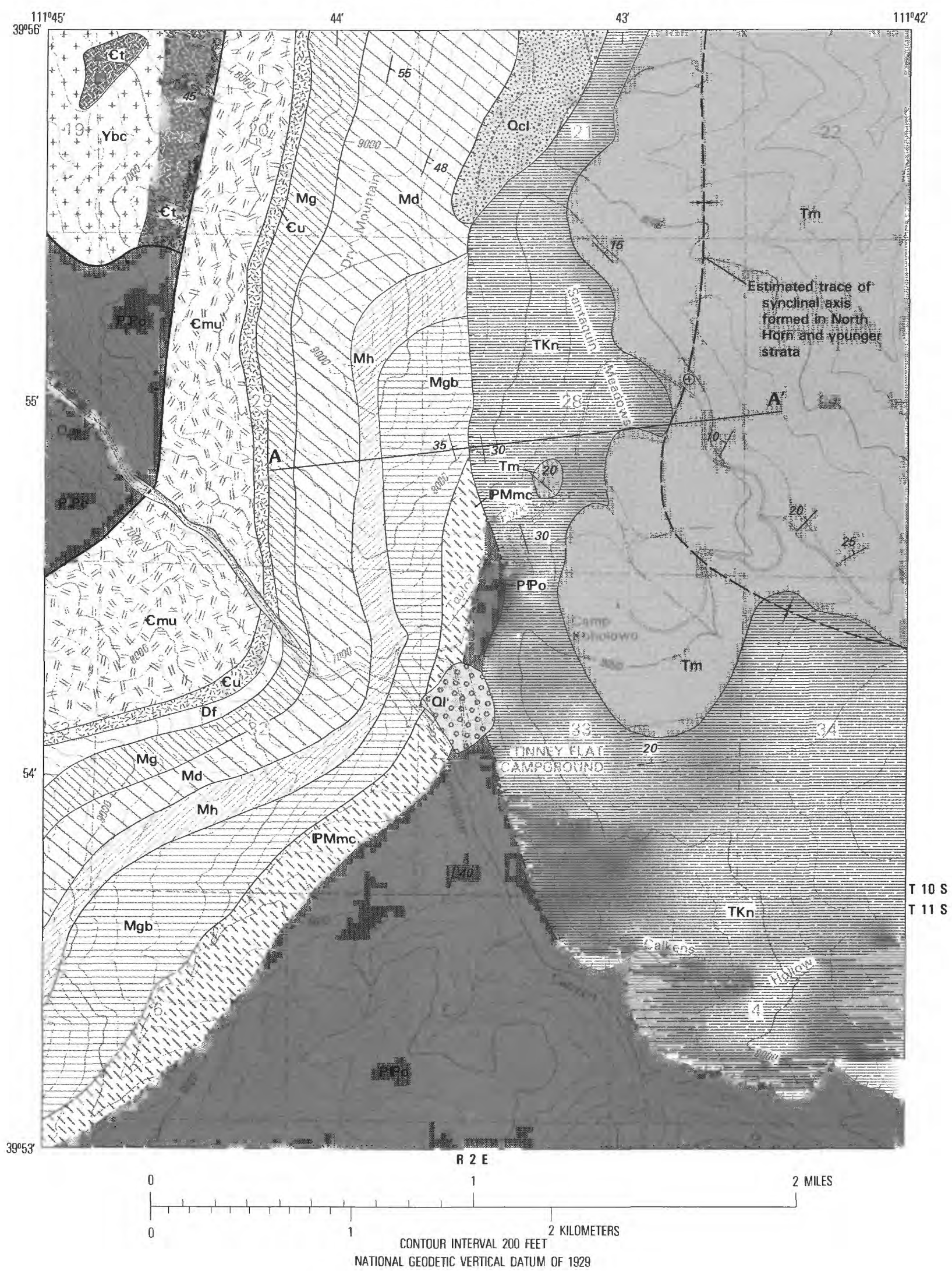


EXPLANATION

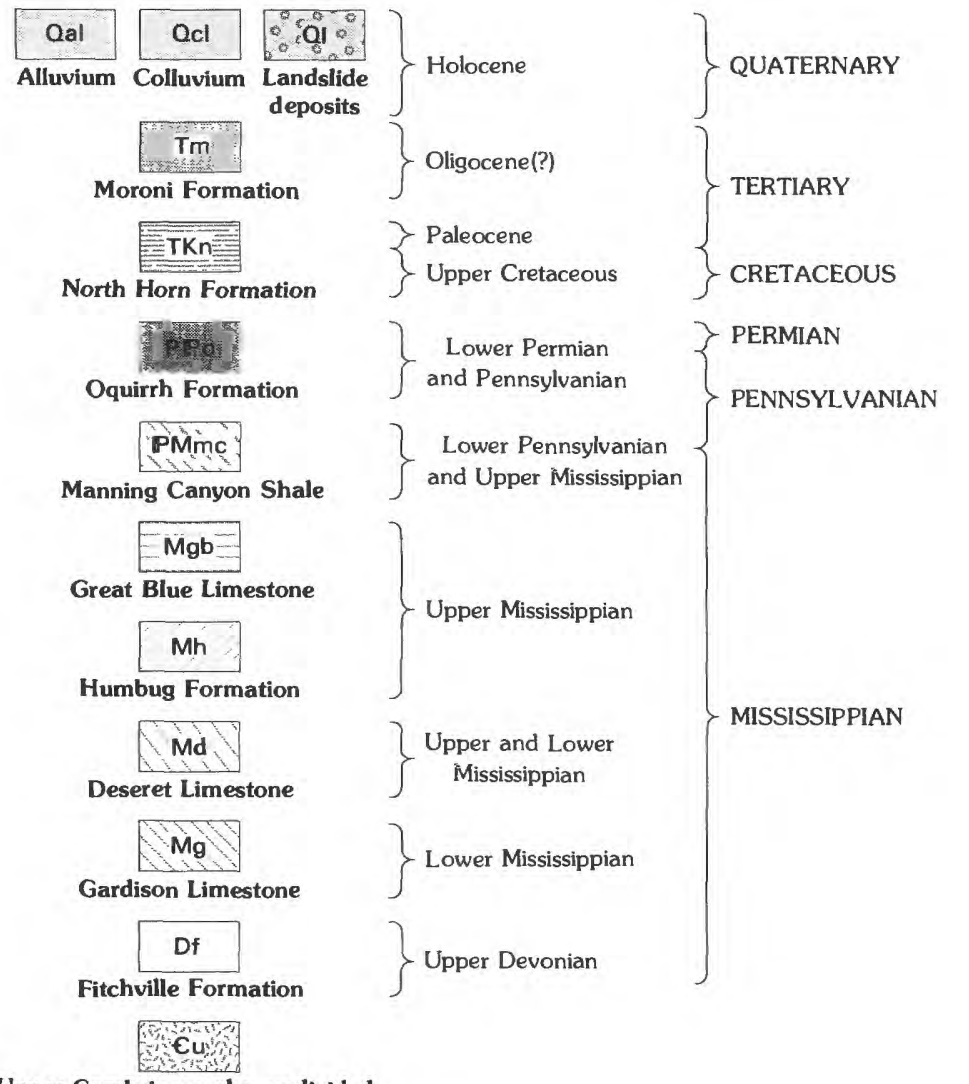

Upper Cambrian rocks, undivided
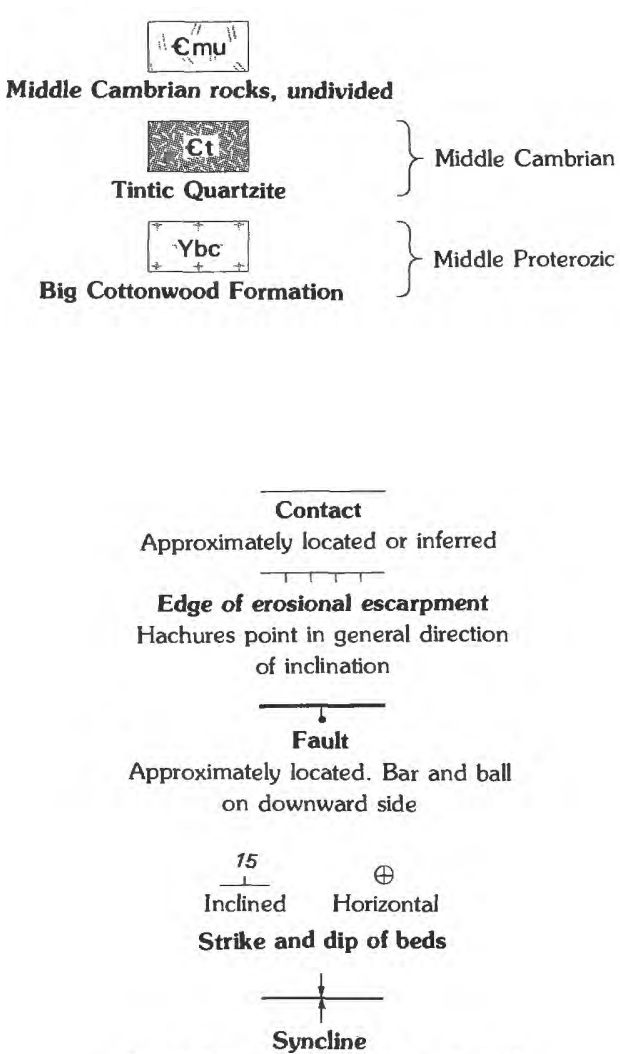

Showing trace of axial plane. Dashed where approximately located
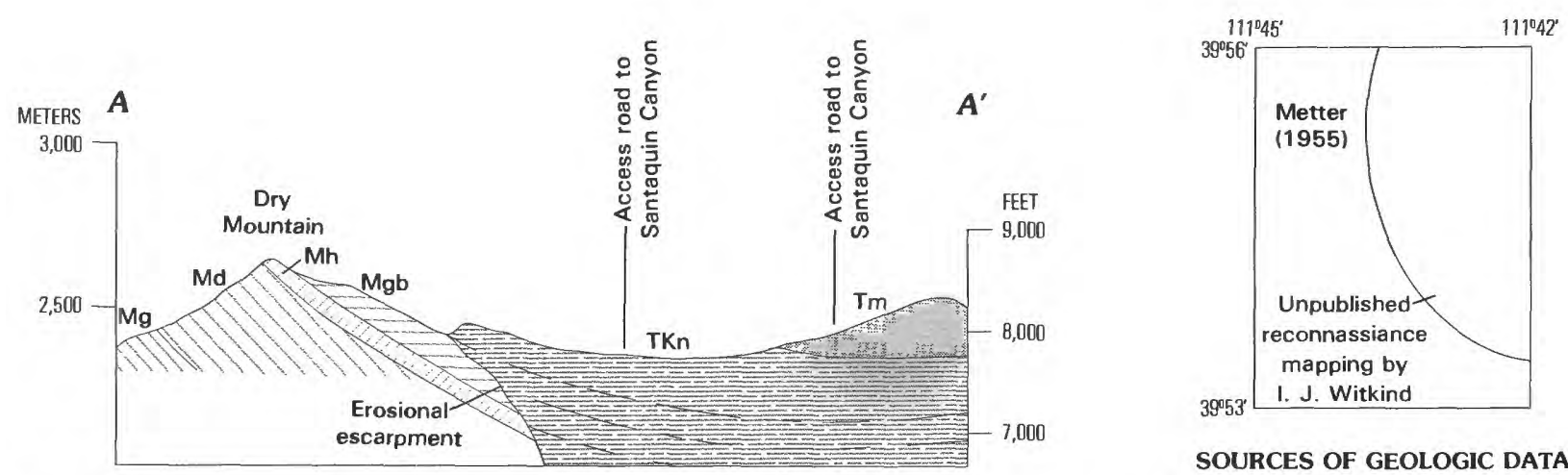

FIGURE 8 (above and facing page).-Geologic map of an area near the head of Santaquin Canyon. In Taylor Fork, the escarpment formed on the Charleston-Nebo thrust plate trends north, and the overlying North Horn (TKn) beds, thus, trend northerly and dip easterly (see fig. $5 B$ for photographic overview of these relations). As these North Horn beds are traced southeastward into Santaquin Canyon, they bend and gradually assume a northeasterly strike and a northwesterly dip reflecting an eastward projection of the escarpment. Cross section is not deep enough to include the Charleston-Nebo thrust fault, which is the sole of the thrust plate.

2. Movement along the Wasatch fault zone has raised and tilted the upper plate of the thrust plate eastward, resulting in eastward tilting of the overlying mantle of North Horn and younger rocks.

3. Uneven compaction, at time of deposition, of uncon- solidated North Horn and younger sediments that were deposited across the eroded thrust plate resulted in the development of a pseudoarch that reflected the buried plate. Erosion of the arch left tilted remnants of North Horn and younger beds. 


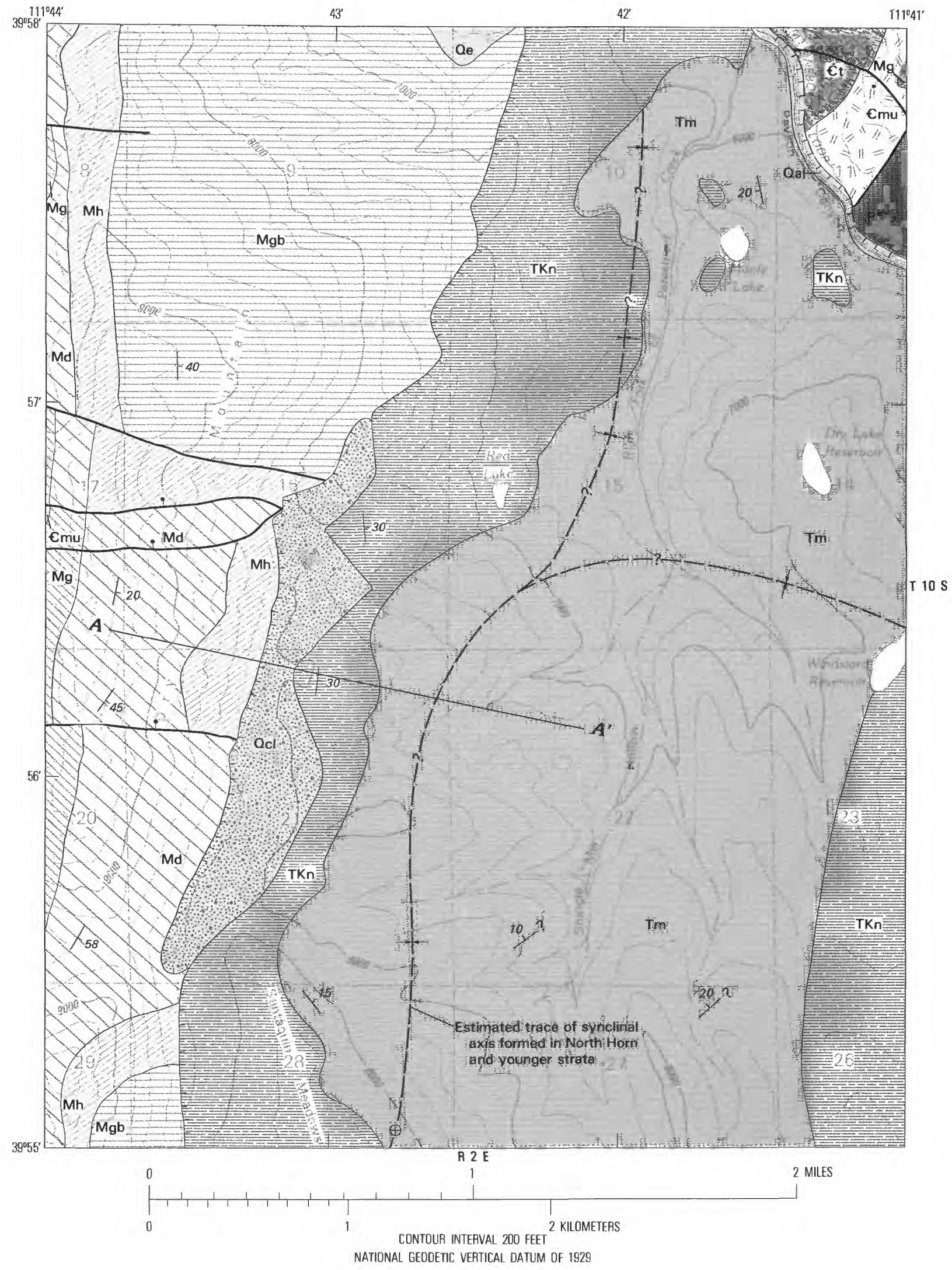


EXPLANATION
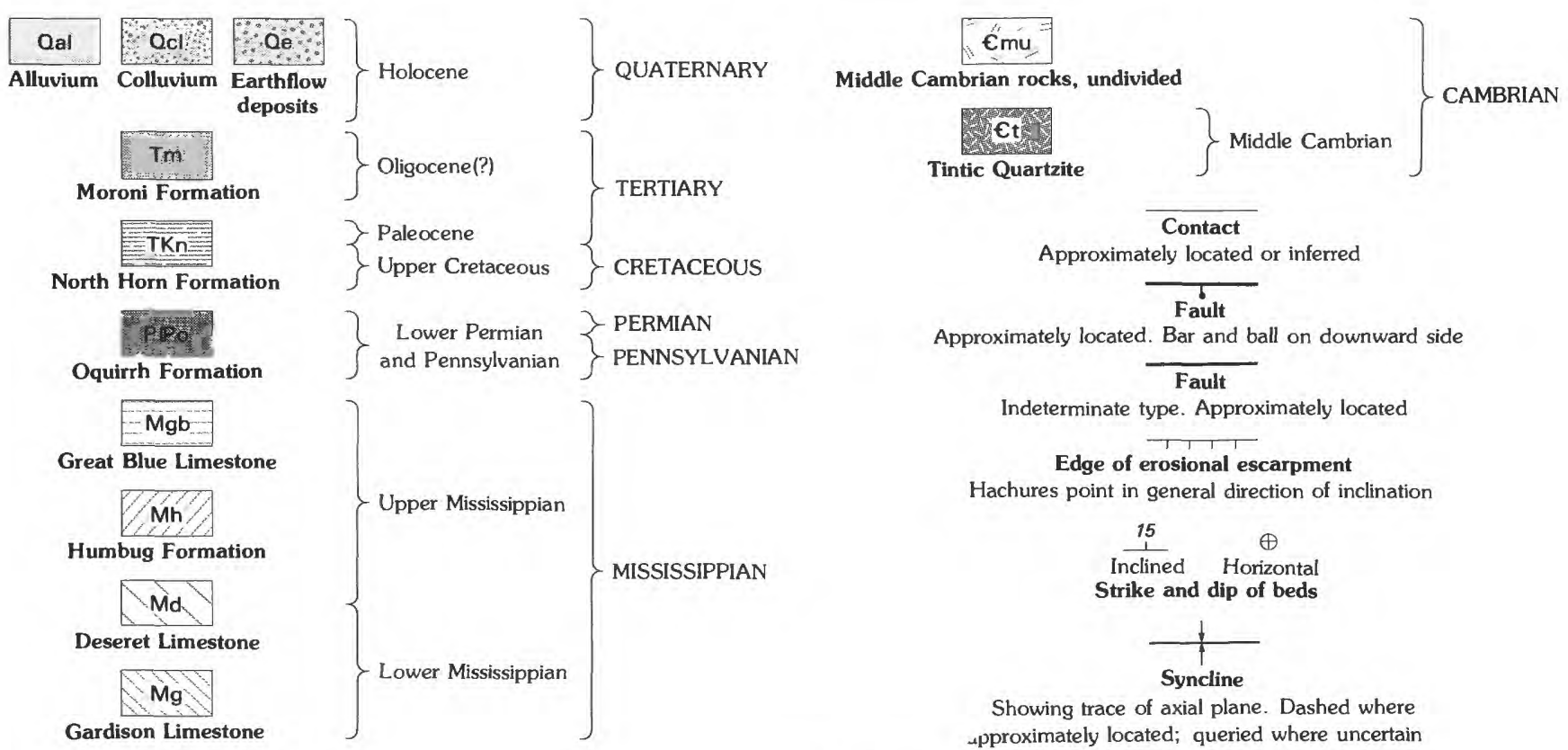

Approximately located. Bar and ball on downward side

$$
\text { Fault }
$$

Indeterminate type. Approximately located

$$
T+1,
$$

Edge of erosional escarpment

Hachures point in general direction of inclination

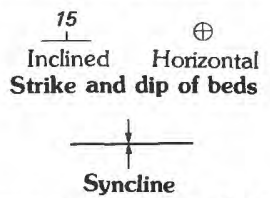

Showing trace of axial plane. Dashed where spproximately located; queried where uncertain

A

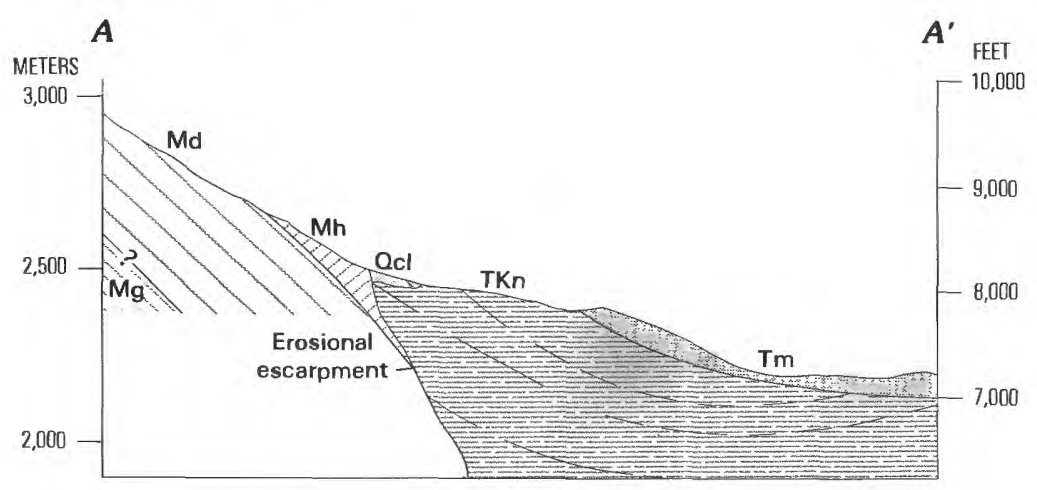

FIGURE 9 (above and facing page).-Geologic map of an area near Red Lake. Clastic beds of the North Horn Formation (TKn) strike northerly and dip easterly, and unconformably overlie a series of undivided Mississippian strata (Mu) that also strike northerly and dip easterly. These Mississippian strata are part of the escarpment formed on the Charleston-Nebo thrust plate. Cross section is not deep enough to include the Charleston-Nebo thrust fault, which is the sole of the thrust plate. See fig. $5 C$ for general photographic overview of this locality.

4. One or more salt-generated structures-diapiric folds-developed beneath the thrust plate and arched parts of the plate and its overlying mantle of younger rocks.

The merits, or lack thereof, of each interpretation are considered in the following subsections.

\section{DRAG ALONG NORMAL FAULT OR FAULTS}

The localized tilt of the North Horn beds may be directly attributable to drag along the downthrown block of a high-angle normal fault that separates the overlying North Horn beds from the Paleozoic rocks of the escarpment. So, for example, in the Thistle Creek area (fig. 11), Metter (1955, fig. 27) suggested that the North Horn and younger beds east of the escarpment are separated from the escarpment by a northeasttrending normal fault (Thistle Canyon fault) along which the beds east of the fault are downthrown. But oddly, faced with almost the same stratigraphic relations in Taylor Fork (fig. 8), Metter (1955, fig. 27) showed eastward-dipping Tertiary (my North Horn Formation) beds overlying the Paleozoic rocks of the thrust plate as the result of a westward-directed thrust fault. This, however, may be an error, because on his cross section $A-A^{\prime}$ across Taylor Fork, he shows the Tertiary units unconformably overlying the Paleozoic rocks that form 


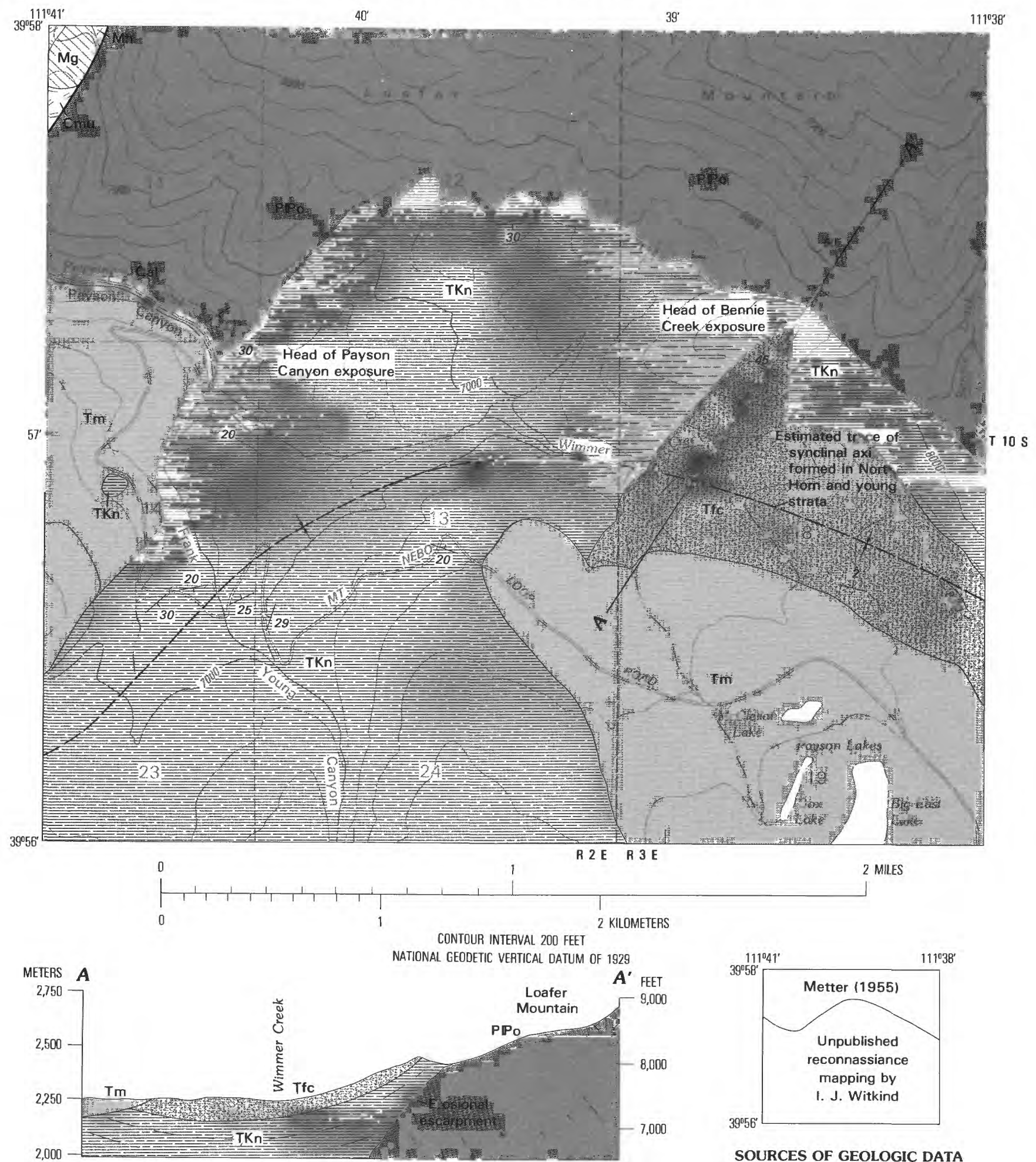

the thrust plate. I have been unable to find any evidence of faulting in either of the localities mentioned.

In other places along the escarpment, such as the Red Lake area, or at the head of Payson Canyon, where tilted North Horn beds are juxtaposed against the Paleozoic rocks of the thrust plate, Metter (1955, fig. 27 , cross sections $A-A^{\prime}$ and $\left.B-B^{\prime}\right)$ indicated that the North Horn beds lie unconformably on the thrust plate.

Although I could find no evidence of normal faults separating the North Horn beds from the thrust plate 


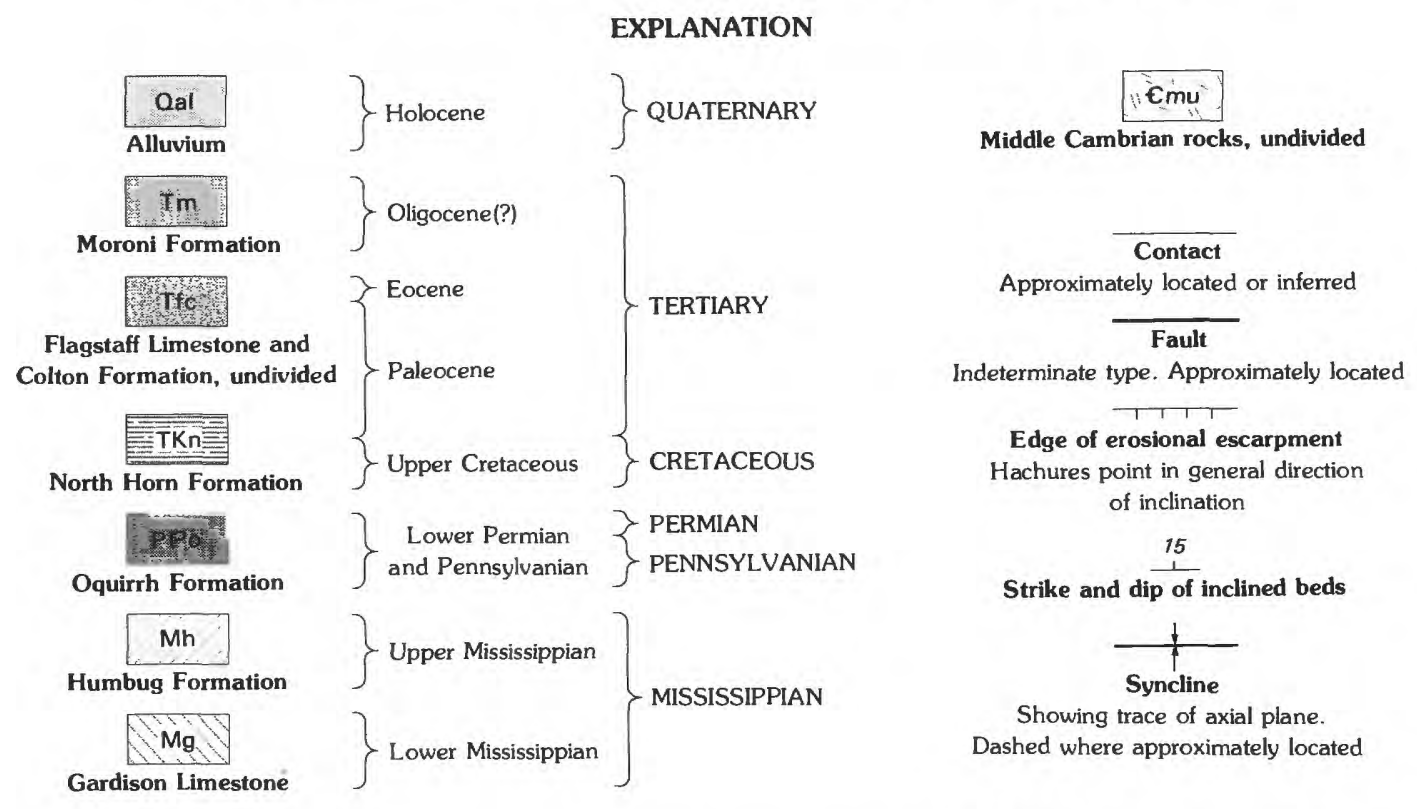

Figure 10 (above and facing page).-Geologic map of an area near the head of Payson Canyon. This area overlies the northern edge of the broad, eastward-facing Santaquin embayment. As a result, the escarpment formed on the Charleston-Nebo thrust fault trends easterly, and the overlying North Horn beds dip southerly. Cross section is not deep enough to include the Charleston- Nebo thrust fault, which is the sole of the thrust plate. See fig. $5 D$ for a photographic overview of the exposure at the head of Payson Canyon, and fig. $5 E$ for an overview of the Bennie Creek exposure.

at the localities discussed above, perhaps such faults do exist. The exact geologic relations are concealed beneath debris and foliage. It seems unlikely, however, that a single, unbroken, high-angle normal fault persists all along the escarpment; such a fault would be marked by an extremely complex and sinuous trace involving several right-angle bends.

Perhaps of even greater significance is the fact that in Salt Creek Canyon (fig. 5A) and at the head of Payson Canyon (fig. $5 D$ ), where exposures are unequivocal, the North Horn strata rest with distinct angular unconformity on the overturned Paleozoic and Mesozoic rocks that form the escarpment.

\section{MOVEMENT ALONG THE WASATCH FAULT ZONE}

Movement along the Wasatch fault zone may have raised and tilted the thrust plate eastward and, in so doing, tilted the overlying North Horn strata eastward too. The Wasatch fault zone trends north and dips steeply to the west; the crustal blocks east of the fault zone are upthrown relative to those blocks west of the zone. Displacement of the shoreline terraces of Lake Bonneville indicate that this is absolute movement- the crustal blocks east of the fault zone have been moving upward at least since Lake Bonneville time (Hunt and others, 1953; p. 39; Hamblin, 1984, p. 119). Consequently, greatest structural relief is along the west edge of the tilted fault block; the east edge-the hinge line-is unchanged, or tilted but slightly eastward. The end result of such uneven uplift of the thrust plate would be a slight eastward tilt of those North Horn strata that overlie the east edge of the plate.

Several factors oppose this concept. First, North Horn beds along the west flank of the mountains (near Santaquin) and east of the Wasatch fault zone dip westerly (fig. 12). Seemingly, differential uplift of the plate, much as proposed above, should result in easterly dips for all North Horn beds that are draped across the plate. Second, although uplift of the plate along the Wasatch fault zone may explain the eastward dip of those North Horn strata that overlie that part of the erosional escarpment that trends north-more or less parallel to the Wasatch fault zone-it seems inadequate to explain the northerly dip of those strata near the head of Santaquin Canyon (fig. 8), or the southerly dip of those North Horn strata in the Payson Canyon and Bennie Creek areas (fig. $5, D, E$ ) where the escarpment trends easterly. 


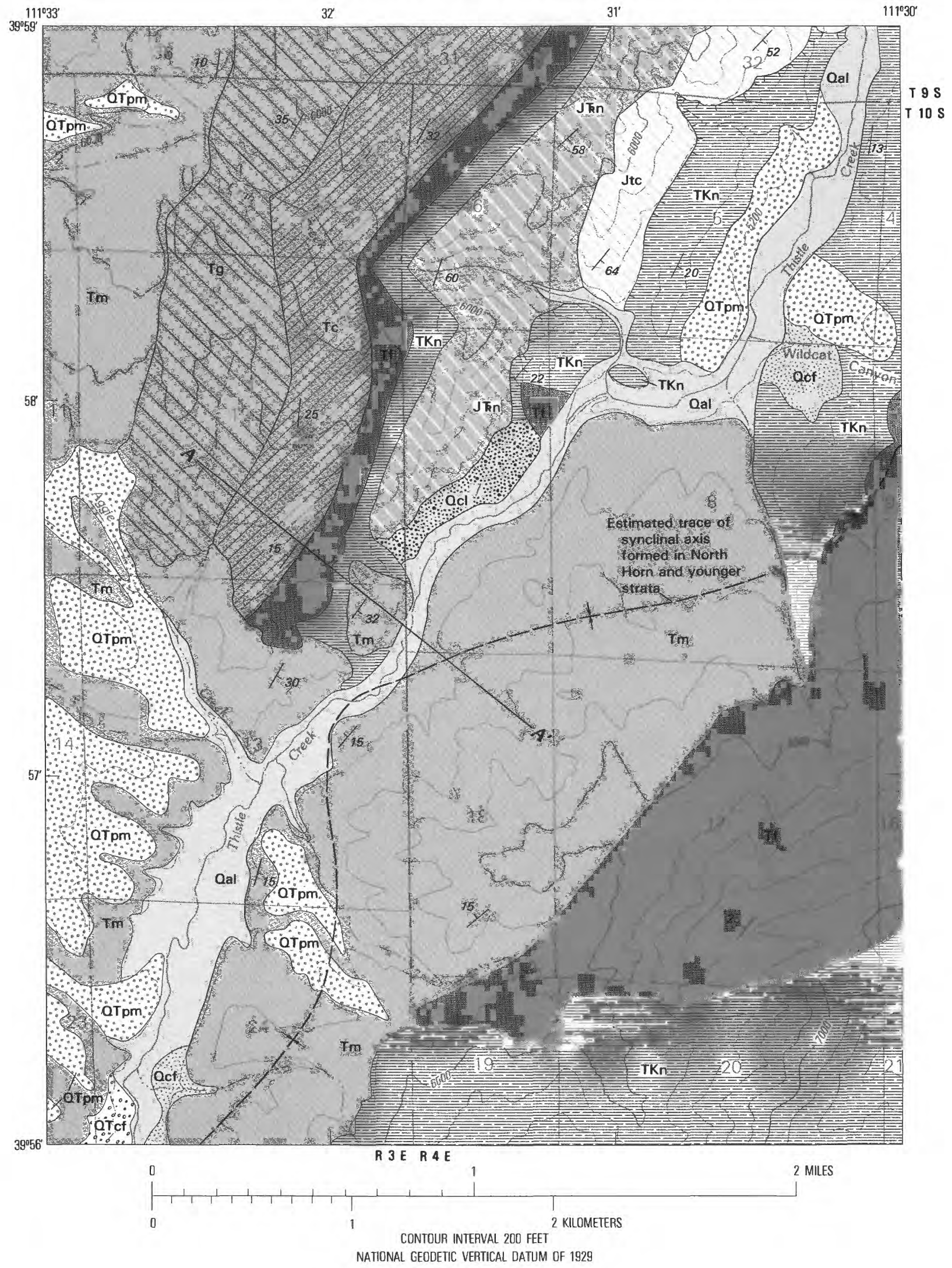




\section{EXPLANATION}

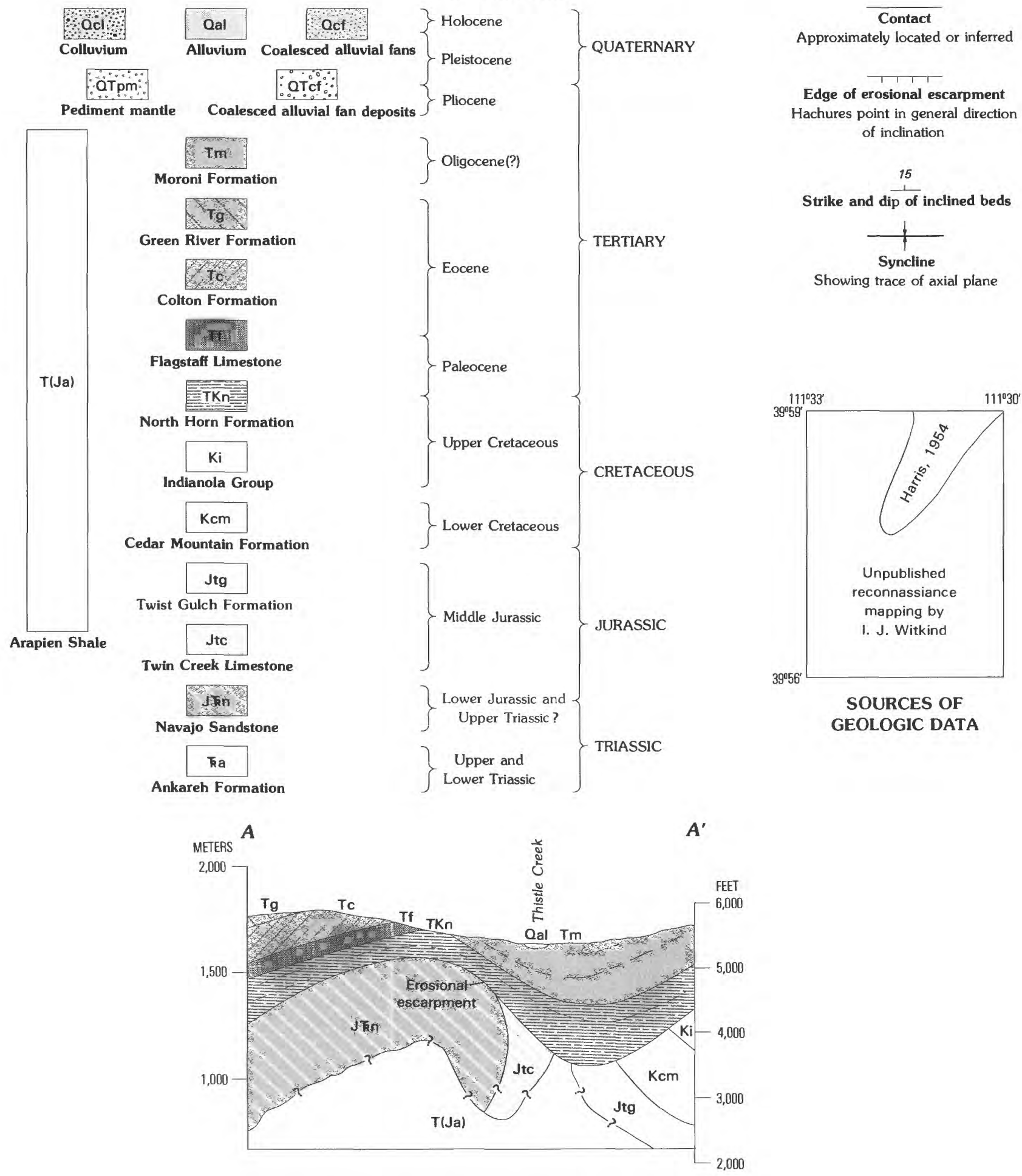

FIGURE 11 (facing page).-Geologic map of an an area along Thistle Creek. Part of the erosional escarpment formed on the Charleston-Nebo thrust plate is exposed in a small gap cut through a folded cover of Cretaceous and Tertiary rocks. The escarpment is represented by steep eastward-dipping beds of the Navajo Sandstone (JTn) and the Twin Creek Limestone (Jtc). The Cretaceous-Tertiary cover is represented by sedimentary beds of the North Horn Formation (TKn), Flagstaff Limestone (Tf), Colton Formation (Tc), and Green River Formation (Tgr), and by volcanic rocks of the Moroni Formation (Tm). The escarpment, well exposed at the northern edge of the map, disappears beneath the sedimentary mantle near the line of cross section $A-A^{\prime}$. Cross section is not deep enough to include the Charleston-Nebo thrust fault, which is the sole of the thrust plate. See fig. $5 F$ for a photographic overview of this locality. 


\section{UNEVEN COMPACTION OF UNCONSOLIDATED NORTH HORN AND YOUNGER SEDIMENTS}

Some upwarps are best explained as the result of differential compaction of unconsolidated sediments that were deposited across a buried topographic high (Oriel and Tracey, 1970, p. 33). A promising anticlinal upwarp, therefore, may be nothing more than the configuration, developed in the younger rocks, of the buried mass. If unconsolidated sediments of the North Horn Formation were deposited across the eroded mass of the Charleston-Nebo thrust plate, the first stage in the pattern envisaged by Oriel and Tracey would be satisfied. Uneven compaction of these clay" and mudrich sediments would result in the development of a pseudoarch that would mirror the buried mass of the plate; North Horn beds east of the máse would dip easterly, and those west of the buried mass would dip westerly. The impression created would be of arched North Horn beds.

Although this interpretation satisfactorily explains the many changes in strike of those North Horn beds that overlie the sinuous trace of the escarpment, it fails to explain the uniformity of dip that marks stacks of tilted strata. Younger overlying strata have dips comparable to those of the underlying North Horn beds.

Uneven compaction of unconsolidated North Horn sediments deposited across the exposed, sloping, and eroded escarpment would result in beds of sedimentary rock that dip away from the buried plate. As younger sediments were deposited on these rocks and then unevenly compacted, the new units would have still lower dips. Unevenly compacted ever younger sediments would give rise to units that have more shallow dips, and these dips would decrease upward as younger sediments were deposited and compacted. The end result would be a stack of sedimentary units with each younger unit marked by somewhat lower dips. This pattern is not apparent within the areas discussed here. For example, in the exposures at the head of Bennie Creek (fig. $5 E$ ), the Flagstaff Limestone beds rest conformably on the underlying North Horn beds and dip southerly. As far as I can determine, both units are parallel and have the same strike and dip. In the Thistle Creek area (fig. 11) volcanic units of the Moroni Formation unconformably overlie the North Horn beds and dip southeasterly at dips that locally are comparable to those on the underlying North Horn units. The impression created is that all units in the sedimentary stack were tilted concurrently.

\section{UPLIFT AS A RESULT OF SALT DIAPIRISM}

An interpretation that I favor proposes that parts of the thrust plate have been raised as a result of the growth of one or more diapiric folds beneath the plate. In a recent article (Witkind, 1983), I suggested how this diapiric activity has deformed the CharlestonNebo allochthon in at least three localities: Gardner Canyon-Red Canyon, Pigeon Creek, and the Thistle area (fig. 3 ).

I believe that two separate and discrete diapiric folds-the Thistle Creek and Levan diapiric folds (fig. 1)-developed beneath the Charleston-Nebo thrust plate. As the folds grew, they raised and arched part of the thrust plate and its overlying mantle of North Horn and younger beds.

\section{THISTLE CREEK DIAPIRIC FOLD}

Evidence supporting the deformation of the thrust plate as a result of the growth of one or more diapiric folds beneath the plate is well exposed in Thistle Creek (fig. 1, no. 11). Near the junction of Crab and Thistle Creeks, a small segment of the escarpment formed on the thrust plate is exposed in a northeast-trending gap cut in folded North Horn and younger strata (fig. 11). The exposed part of the thrust plate consists of beds of the Navajo Sandstone (JRn) and Twin Creek Limestone (Jtc) that dip steeply eastward. These Navajo and Twin Creek outcrops are overlain, on the west, by North Horn (TKn) and younger beds that dip gently to moderately westward, and on the east, by North Horn and younger beds that dip gently eastward.

Apparently, the erosional escarpment formed on the thrust plate was originally buried beneath nearly horizontal North Horn and younger strata. As a diapiric fold developed beneath the thrust plate, it raised the plate and in so doing arched the overlying younger rocks. Erosion has since removed the crestal part of the arched sheet of North Horn and younger rocks and exhumed part of the escarpment. Near the junction of Aggie Creek and Thistle Creek (fig. 11), the gap eroded in the crest of the arched younger rocks gradually narrows and then ends as it passes beneath folded North Horn units that are draped across and conceal the escarpment (fig. 11, cross section $A-A^{\prime}$ ).

Further, the Arapien Shale-the intrusive unit believed responsible for the upwarp of the thrust platecrops out in this general area and near Thistle where it both deforms Tertiary strata (Witkind, 1983, p. 55) and intrudes Twin Creek units (fig. 4). 
Although the Navajo and Twin Creek strata show no evidence of being warped up, the anticline formed in the overlying North Horn beds implies that these units were indeed raised by the developing diapiric fold.

\section{LEVAN DIAPIRIC FOLD}

I believe that the Levan diapiric fold (fig. 1, no. 3) has also deformed the Charleston-Nebo allochthon. The exposed core of the Levan fold is a belt of Arapien Shale that trends about N. $15^{\circ} \mathrm{E}$. along the northwest flank of the Gunnison Plateau. The belt extends from Little Salt Creek on the south to Red Canyon on the north (fig. 3), a distance of some $40 \mathrm{~km}$ ( $25 \mathrm{mi}$ ). Younger consolidated sedimentary strata on both sides of the Arapien exposure dip outward and represent the limbs of the fold. The fold continues northward beneath the thrust plate and locally deforms the plate in the Gardner Canyon-Red Canyon area (Witkind, 1983, p. 51-54, fig. 4).

I do not know how far to the north the fold continues beneath the plate; a tongue of Arapien Shale reaches almost to the head of Footes Canyon (fig. 3 ) before it disappears beneath the Mesozoic and Paleozoic rocks of the thrust plate. Possibly the concealed fold extends as far north as Santaquin Canyon, as suggested by isolated outcrops of tilted North Horn beds exposed on both sides of the thrust plate. These seem to be remnants of a former continuous cover of North Horn and younger beds draped across the thrust plate. Along the east flank of the southern Wasatch Mountains, in the Taylor Fork and Red Lake areas, the North Horn and younger beds dip easterly. Directly to the west, on the opposite side of the mountains, patches of the North Horn Formation overlain by small eroded remnants of the Flagstaff Limestone dip westerly (fig. 12). These opposing dips developed in North Horn and younger strata exposed on opposite sides of the mountains suggest that an anticlinal fold was formed in these younger beds above an arched thrust plate, much as exposed in the Thistle Creek area. And, as in the Thistle Creek area, the rocks that form the thrust plate give no hint that they were once uplifted.

If the Levan diapiric fold does underlie part of the thrust plate, as I suspect, it trends northerly and is at least $65 \mathrm{~km}(40 \mathrm{mi})$ long.

The folded cover of Cretaceous and Tertiary rocks draped across that part of the escarpment exposed in Thistle Creek (fig. 11) serves as an example of the type of anticline that must have been formed along the remainder of the escarpment. Erosion, however, has created fundamental differences. In the Thistle Creek area, only a small gap has been cut into the mantling North Horn and younger sedimentary cover. By contrast, over much of the area, the bulk of the overlying North Horn and younger beds has been removed, leaving only remnants, chiefly along the escarpment formed on the thrust plate.

\section{UNLOADING}

If diapiric folds did indeed deform the thrust plate, is there a possibility that these folds formed as a result of the erosion and consequent unloading of the plate? McKnight (1940, p. 123-124), discussing the Meander anticline near Moab, Utah, proposed that the anticline, so named because it follows a meander of the Colorado River, occupies this position solely as a result of channeling by the river. Removal of the overlying rocks resulted in upward movement of the underlying salt of the Paradox Member of the Hermosa Formation, which bulged the canyon floor to form the anticline. The coincidence between the anticline and the meander is unmistakable. By contrast, in the Sanpete-Sevier Valley area, the diapiric folds extend throughout the area (fig. 1) and seem wholly independent of and unrelated to the escarpment formed on the thrust plate. Many folds are distant from the thrust plate and, although some folds near the thrust plate do parallel the escarpment, other nearby folds trend at an angle to it. The general impression created is that the folds were formed independently of the escarpment.

\section{DIAPIRIC FOLD(?) IN THE SANTAQUIN EMBAYMENT}

In four of the nine areas discussed above, a diapiric fold forms the east flank of the bordering syncline. For example, in the Salt Creek area, the Pole Creek fold (fig. 1 , no. 12) borders the syncline on the east. In both the Black Canyon area and along the east flank of Loafer Mountain, the syncline is bordered on the east by the Thistle Creek fold (fig. 1, no. 11). In the Thistle Creek area, the Dry Hollow fold (fig. 1, no. 10) forms the east flank of the syncline. By contrast, I am uncertain just what structural element forms the syncline's east flank in the Santaquin embayment (the site of the remaining five areas discussed). In the embayment, the syncline forms a U-shaped curve open to the southeast (fig. 3), and the critical structural element thus underlies the center of the embayment. Regrettably, this central part of the embayment is covered with thick foliage and is underlain in great part both by mudstone and claystone beds of the North Horn Formation and by pyroclastic 

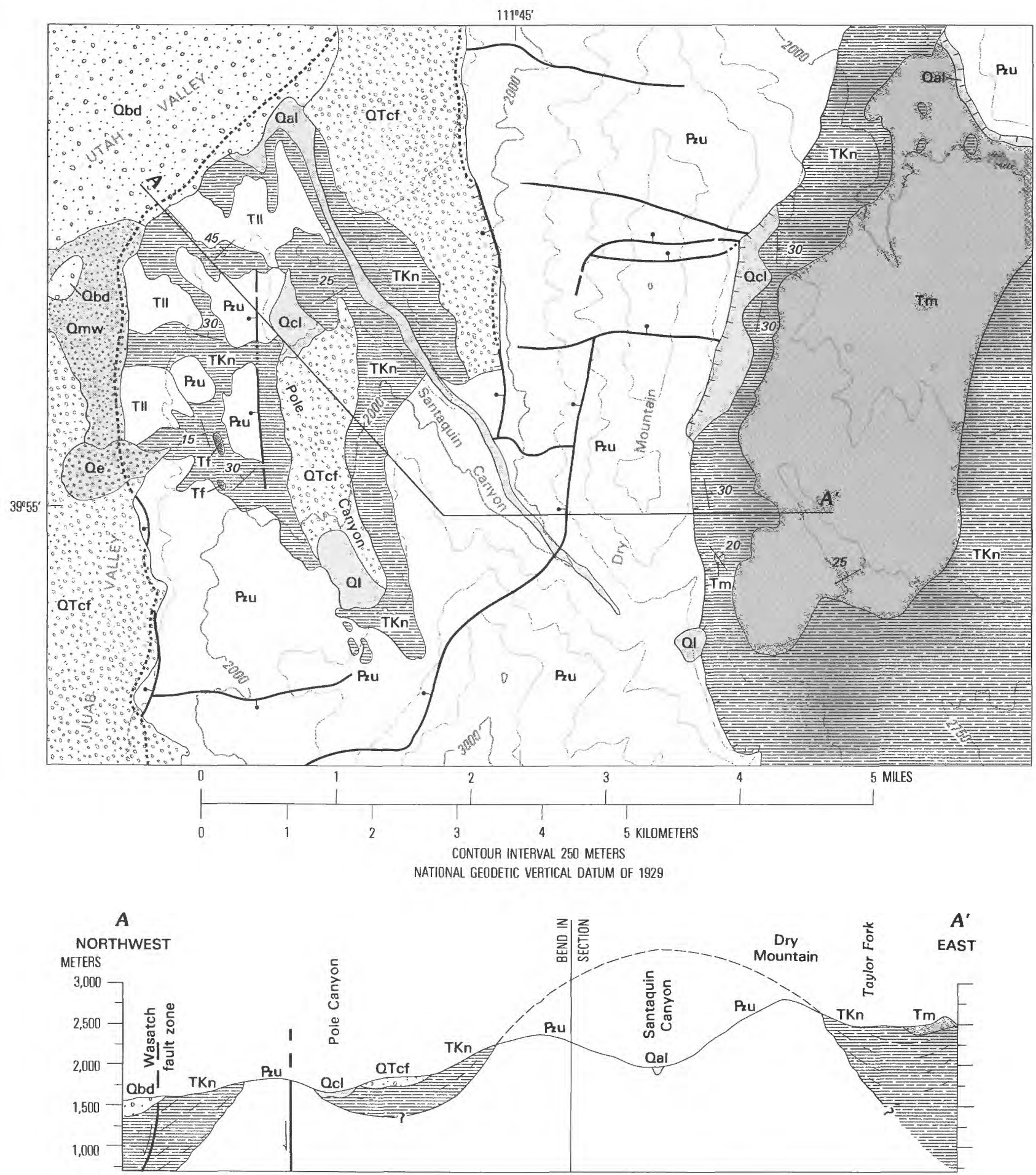

rocks of the Moroni Formation. Both formations weather as low, rubble-covered slopes marked by sparse, discrete outcrops, few of which are suitable for the measurement of strike and dip. On the basis of a few exposures, I believe that the north and northwest-trending Gentle Band and Amos Backbone Ridges (fig. 3) are part of the crest of an underlying diapiric fold. North Horn beds that form the east flanks of the ridges dip 20-25 eastward and northeastward; beds along the west flanks of the ridges dip about $10^{\circ}$ westward and southwestward. I suspect that this concealed fold(?) extends into the embayment as a northwest-trending offshoot of the 
EXPLANATION
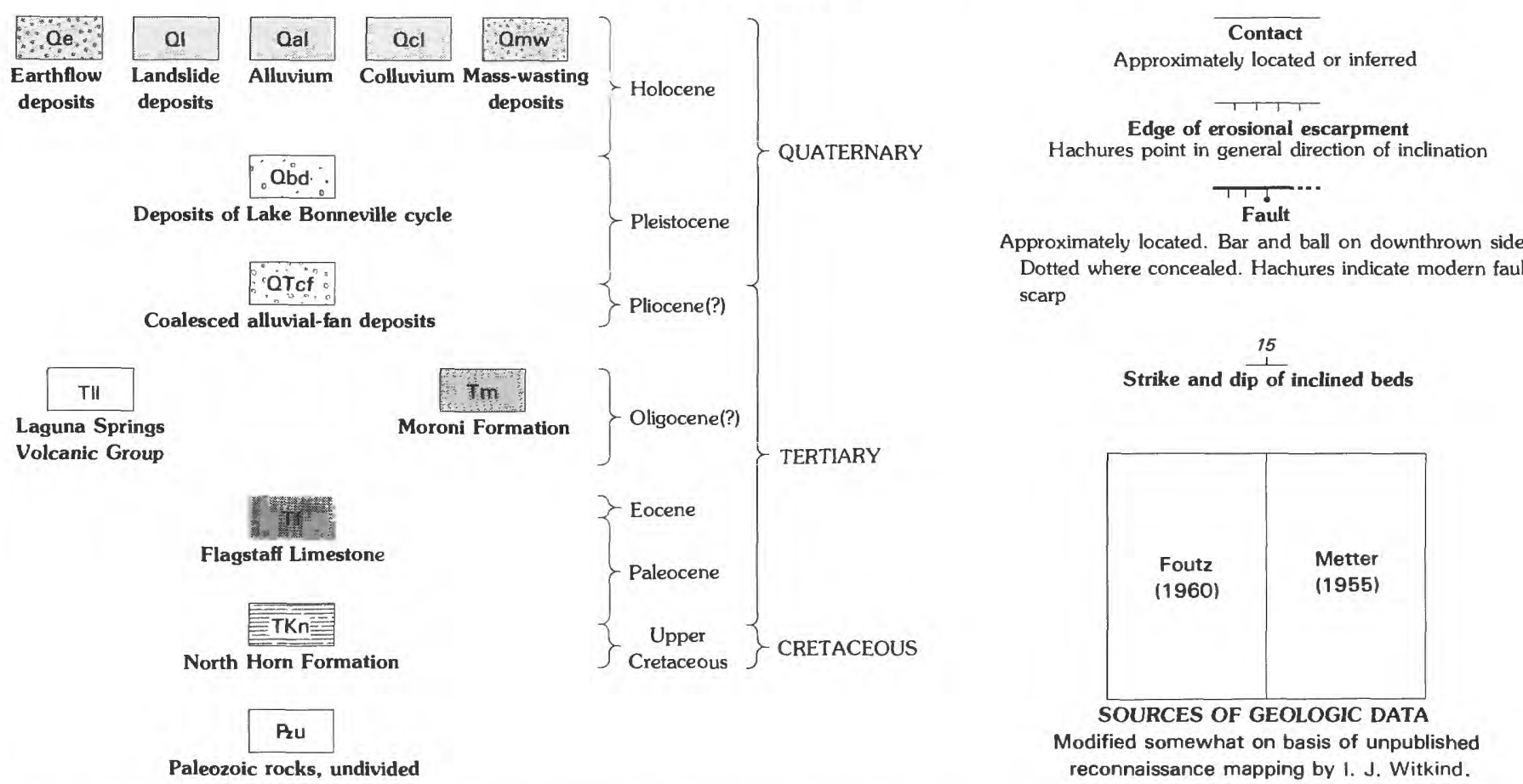

FIGURE 12 (facing page).-Geologic map of an area near Dry Mountain. North Horn strata that flank the north to northeasterly trending southern Wasatch Mountains dip easterly east of the range and westerly west of the range. These opposing dips suggest that an anticlinal fold was developed in these younger strata above an arched thrust plate.

Thistle Creek diapiric fold (fig. 1, no. 11). Comparable relations between folds are found southwest of the Gunnison Plateau where the Sevier Bridge Reservoir fold (fig. 1, no. 4) extends northwestward, in tributary-like fashion, from the Redmond fold (fig. 1, no. 2).

\section{CONCLUSIONS}

Although other explanations for the deformation along the east flank of the Charleston-Nebo thrust plate, as discussed in this paper, seem reasonable, I believe that only two-differential compaction of unconsolidated sediments, and salt diapirism - are acceptable alternatives. Inadequate exposures preclude complete acceptance of either; I believe, however, that salt diapirism is the best explanation. Almost all the structural complexity in the Sanpete-Sevier Valley area is most reasonably and simply explained as the result of the repeated growth and collapse of salt-generated diapiric folds. These recurrent episodes of salt diapirism, which began during the Mesozoic and have persisted into the Quaternary, have stamped a unique geologic pattern-determined by the diapiric folds-on this sector of central Utah. It seems unreasonable to assume that these diapiric folds are restricted only to that part of the area that lies in front of the thrust plate. The folds must be impressed on that part of the area overlain by the thrust sheet; if so, the folds must have deformed the allochthon, too.

Consequently, I propose that the Thistle Creek and Levan diapiric folds raised parts of the thrust plate after the plate was emplaced, eroded, and then covered by North Horn and younger strata. As a result, the overlying North Horn and younger beds were arched more or less uniformly. The attitudes assumed by the arched North Horn and younger beds were determined by the configuration of that part of the erosional escarpment on which they rested. This would explain the general easterly tilt of those North Horn and younger beds that rest on that part of the escarpment that trends north, the northerly dip of North Horn strata in Santaquin Canyon where they overlie the north flank of an eastward-directed protuberance of the escarpment, and the southerly and southwesterly dips of similar strata exposed along the south flank of Loafer Mountain, where North Horn and younger beds overlie the sinuous south flank of the east-trending escarpment.

The following sequence of major events determined the structural evolution of the Charleston-Nebo allochthon: 
1. Eastward and southeastward emplacement of the allochthon along the Charleston-Nebo thrust fault at some time prior to deposition of the North Horn Formation (Maestrichtian Stage of the Late Cretaceous) but after deposition of the Twin Creek Limestone (Bajocian, Bathonian, and Callovian Stages of the Middle Jurassic).

2. Extensive erosion of the thrust plate during transport and after it came to rest, probably in Early and early Late Cretaceous time.

3. Burial of the thrust plate beneath North Horn and younger strata during the Late Cretaceous and Tertiary.

4. Uplift of parts of the plate by one or more diapiric folds, probably in Miocene time, resulting in the arching of the Cretaceous and Tertiary cover.

5. Block faulting and erosion during late Tertiary and Quaternary time during which much of the Cretaceous-Tertiary mantle was removed and parts of the plate were exhumed.

6. Continued block faulting and erosion during the Quaternary to achieve the present configuration.

\section{REFERENCES CITED}

Baer, J. L., 1976, Structural evolution of central Utah-Late Permian to Recent: Rocky Mountain Association of Geologists Guidebook, 27th Annual Field Conference, Geology of the Cordilleran Hingeline, p. 37-45.

Baker, A. A., Huddle, J. W., and Kinney, D. M., 1949, Paleozoic geology of the north and west sides of Uinta Basin, Utah: American Association of Petroleum Geologists Bulletin, v. 33, p. 1161-1197.

Bissell, H. J., 1962, Pennsylvanian-Permain Oquirrh basin of Utah: Brigham Young University Geology Studies, v. 9, pt. 1, p. 26-49.

Black, B. A., 1965, Nebo overthrust, southern Wasatch Mountains, Utah: Brigham Young University Geology Studies, v. 12, p. 55-89.

Brady, M. J., 1965, Thrusting in the southern Wasatch Mountains, Utah: Brigham Young University Geology Studies, v. 12, p. 3-53.

Crittenden, M. D., Jr., 1961, Magnitude of thrust faulting limits in northern Utah: U.S. Geological Survey Professional Paper 424-D, p. D128-D131.

Davis, F. D., 1983, Geologic map of the southern Wasatch front, Utah: Utah Geological and Mineral Survey Map 55-A (two sheets).

Eardley, A. J., 1933a, Stratigraphy of the southern Wasatch Mountains, Utah: Michigan Academy of Science, Arts, and Letters, v. 18 , p. $307-344$

$1933 \mathrm{~b}$, Structure and physiography of the southern Wasatch Mountains, Utah: Michigan Academy of Science, Arts, and Letters, v. 19 , p. $377-400$.

Foutz, D. R., 1960, Geology of the Wash Canyon area, southern Wasatch Mountains, Utah: Brigham Young University Geology Studies, v. 7, no. 2, p. 1-37.

Gilliland, W. N., 1948, Geology of the Gunnison quadrangle, Utah: Columbus, Ohio, Ohio State University, unpublished Ph. D. thesis, $178 \mathrm{p}$.

1951, Geology of the Gunnison quadrangle, Utah: University of Nebraska Studies, new series, no. 8, $101 \mathrm{p}$.
Hamblin, W. K., 1984, Direction of absolute movement along the boundary faults of the Basin and Range-Colorado Plateau margin: Geology, v. 12, p. 116-119.

Hardy, C. T., 1962, Mesozoic and Cenozoic stratigraphy of northcentral Utah: Brigham Young University Geology Studies, v. 9, pt. 1, p. 50-64.

Hardy, C. T., and Zeller, H. D., 1953, Geology of the west-central part of the Gunnison Plateau, Utah: Geological Society of America Bulletin, v. 64, p. 1261-1278.

Harris, H. D., 1954, Geology of the Birdseye area, Thistle Creek Canyon, Utah: The Compass, v. 31, no. 3, p. 189-208.

Hintze, L. F., 1962, Geology of the southern Wasatch Mountains and vicinity, Utah: Brigham Young University Geology Studies, v. 9 , pt. 1, p. $70-80$.

Hunt, C. B., Varnes, H. D., and Thomas, H. E., 1953, Lake Bonneville geology of northern Utah Valley, Utah: U.S. Geological Survey Professional Paper 257-A, 99 p.

Johnson, K. D., 1959, Structure and stratigraphy of the Mount NeboSalt Creek area, southern Wasatch Mountains, Utah: Provo, Utah, Brigham Young University, unpublished M.S. thesis, 49 p.

Lawton, T. F., 1985, Style and timing of frontal structures, thrust belt, central Utah: American Association of Petroleum Geologists Bulletin, v. 69, no. 7, p. 1145-1159.

LeVot, Michel, 1984, L'overthrust belt face aux Uinta Mountains (Utah, U.S.A.): University of Brest, France, unpublished Ph. D. thesis, $278 \mathrm{p}$.

McGookey, D. P., 1960, Early Tertiary stratigraphy of part of central Utah: American Association of Petroleum Geologists Bulletin, v. 44 , no. 5 , p. $589-615$.

McKnight, E. T., 1940, Geology of area between Green and Colorado Rivers, Grand and San Juan Counties, Utah: U.S. Geological Survey Bulletin $908,147 \mathrm{p}$.

Metter, R. E., 1955, The geology of a part of the southern Wasatch Mountains, Utah: Columbus, Ohio, Ohio State University, unpublished $\mathrm{Ph}$. D. thesis, $244 \mathrm{p}$.

Morris, H. T., 1983, Interrelations of thrust and transcurrent faults in the central Sevier orogenic belt near Leamington, Utah: Geological Society of America Memoir 157, p. 75-81.

Moulton, F. C., 1975, Lower Mesozoic and Upper Paleozoic petroleum potential of the hingeline area, central Utah: Rocky Mountain Association of Geologists Guidebook, Deep Drilling Frontiers in the Central Rocky Mountains, p. 87-97.

Oriel, S. S., and Tracey, J. I., Jr., 1970, Uppermost Cretaceous and Tertiary stratigraphy of Fossil Basin, southwestern Wyoming: U.S. Geological Survey Professional Paper 635, 53 p.

Rigby, J. K., and Clark, D. L., 1962, Devonian and Mississippian Systems in central Utah: Brigham Young University Geology Studies, v. 9, pt. 1, p. 17-25.

Schoff, S. L., 1951, Geology of the Cedar Hills, Utah: Geological Socie ty of America Bulletin, v. 62, p. 619-645.

Spieker, E. M., 1946, Late Mesozoic and early Cenozoic history of central Utah: U.S. Geological Survey Professional Paper 205-D, p. 117-161.

1949, The transition zone between the Colorado Plateaus and the Great Basin in central Utah: Utah Geological Society, Guidebook to the geology of Utah, no. 4, $106 \mathrm{p}$.

Standlee, L. A., 1982, Structure and stratigraphy of Jurassic rocks in central Utah: their influence on tectonic development of the Cordilleran foreland thrust belt, in Guidebook, Geologic studies of the Cordilleran thrust belt: Denver, Colo., Rocky Mountain Association of Geologists, 1983, v. I, p. 357-382.

Stokes, W. L., 1952, Salt-generated structures of the Colorado Plateau and possible analogies [abs.]: American Association of Petroleum Geologists Bulletin, v. 36 , no. 5, p. 961 . 
1956, Tectonics of Wasatch Plateau and near-by areas [abs.]: American Association of Petroleum Geologists Bulletin, v. 40, no. 4 , p. 790 .

Tooker, E. W., 1983, Variations in structural style and correlation of thrust plates in the Sevier foreland thrust belt, Great Salt Lake area, Utah: Geological Society of America Memoir 157, p. 61-73.
Witkind, I. J., 1982, Salt diapirism in central Utah, in Nielsen, D. L., ed., Overthrust belt of Utah Symposium: Utah Geological Association Publication 10, p. 13-30.

1983, Overthrusts and salt diapirs, central Utah: Geological Society of America Memoir 157, p. 45-59. 
